\title{
Cannabidiol and Other Non-Psychoactive Cannabinoids for Prevention and Treatment of Gastrointestinal Disorders: Useful Nutraceuticals?
}

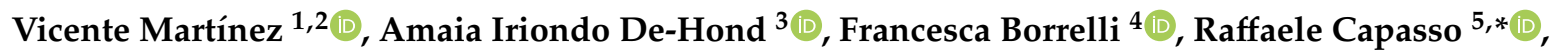 \\ María Dolores del Castillo ${ }^{3}\left[\right.$ and Raquel Abalo ${ }^{6,7}$ (i)
}

1 Department of Cell Biology, Physiology and Immunology, Neurosciences Institute, Universitat Autònoma de Barcelona, 08193 Bellaterra, Barcelona, Spain; vicente.martinez@uab.es

2 Centro de Investigación Biomédica en Red de Enfermedades Hepáticas y Digestivas (CIBERehd), Instituto de Salud Carlos III, 28049 Madrid, Spain

3 Instituto de Investigación en Ciencias de la Alimentación (CIAL) (UAM-CSIC), C/Nicolás Cabrera, 9, Campus de la Universidad Autónoma de Madrid, 28049 Madrid, Spain; amaia.iriondo@csic.es (A.I.D.-H.); mdolores.delcastillo@csic.es (M.D.d.C.)

4 Department of Pharmacy, School of Medicine and Surgery, University of Naples Federico II, Via Domenico Montesano 49, 80131 Naples, Italy; franborr@unina.it

5 Department of Agricultural Sciences, University of Naples Federico II, Via Università 100, 80055 Portici (NA), Italy

6 High Performance Research Group in Physiopathology and Pharmacology of the Digestive System NeuGut-URJC, Department of Basic Health Sciences, Faculty of Health Sciences, Universidad Rey Juan Carlos (URJC), Campus de Alcorcón, Avda. de Atenas s/n, 28022 Madrid, Spain

7 Unidad Asociada I+D+i del Instituto de Química Médica (IQM), Consejo Superior de Investigaciones Científicas (CSIC), Madrid, Spain; raquel.abalo@urjc.es

* Correspondence: rafcapas@unina.it; Tel.: +39-081-678664

Received: 24 March 2020; Accepted: 22 April 2020; Published: 25 April 2020

\begin{abstract}
Cannabis sativa is an aromatic annual flowering plant with several botanical varieties, used for different purposes, like the production of fibers, the production of oil from the seeds, and especially for recreational or medical purposes. Phytocannabinoids (terpenophenolic compounds derived from the plant), include the well-known psychoactive cannabinoid $\Delta^{9}$-tetrahydrocannabinol, and many non-psychoactive cannabinoids, like cannabidiol. The endocannabinoid system (ECS) comprises of endocannabinoid ligands, enzymes for synthesis and degradation of such ligands, and receptors. This system is widely distributed in the gastrointestinal tract, where phytocannabinoids exert potent effects, particularly under pathological (i.e., inflammatory) conditions. Herein, we will first look at the hemp plant as a possible source of new functional food ingredients and nutraceuticals that might be eventually useful to treat or even prevent gastrointestinal conditions. Subsequently, we will briefly describe the ECS and the general pharmacology of phytocannabinoids. Finally, we will revise the available data showing that non-psychoactive phytocannabinoids, particularly cannabidiol, may be useful to treat different disorders and diseases of the gastrointestinal tract. With the increasing interest in the development of functional foods for a healthy life, the non-psychoactive phytocannabinoids are hoped to find a place as nutraceuticals and food ingredients also for a healthy gastrointestinal tract function.
\end{abstract}

Keywords: cannabidiol; cannabinoids; inflammatory bowel disease; irritable bowel syndrome; gastrointestinal; non-psychoactive cannabinoids; nutraceutical; psychoactive cannabinoids; visceral pain 


\section{Introduction}

Dietary effects of nutraceuticals on gastrointestinal (GI) health are well recognized, and specific diets have been related to the prevention or the reduction of incidence of certain GI pathologies. Moreover, specific food ingredients, mediating these effects, have been characterized and isolated, and their efficacy assessed experimentally. This evidence supports the general use of nutraceuticals and food ingredients for the treatment and prevention of GI diseases or the overall promotion of GI health [1]. Moreover, the wide acceptance and use of complementary and alternative medicine by patients with inflammatory and functional GI disorders [2,3] further supports the interest in developing nutraceuticals targeting the GI tract.

Among the possible plant-derived nutraceuticals for treatment of GI disorders are those from Cannabis. Cannabis is a generic term used to indicate preparations obtained from the plant Cannabis sativa, an aromatic annual flowering herb. There is debate and confusion over the taxonomic organization of Cannabis. However, John M. McPartland concluded in a scientific review that the family Cannabaceae includes genera Cannabis, Humulus, and Celtis. In the genus Cannabis, the species sativa has three varieties, sativa, indica and ruderalis [4], which are discussed in the present review. Figure 1 shows de morphologic differences between the three varieties of Cannabis sativa. Importantly, depending on the variety, Cannabis sativa can be used for several purposes, including the production of fibers, the production of oil from the seeds, and mainly for recreational or medical purposes.

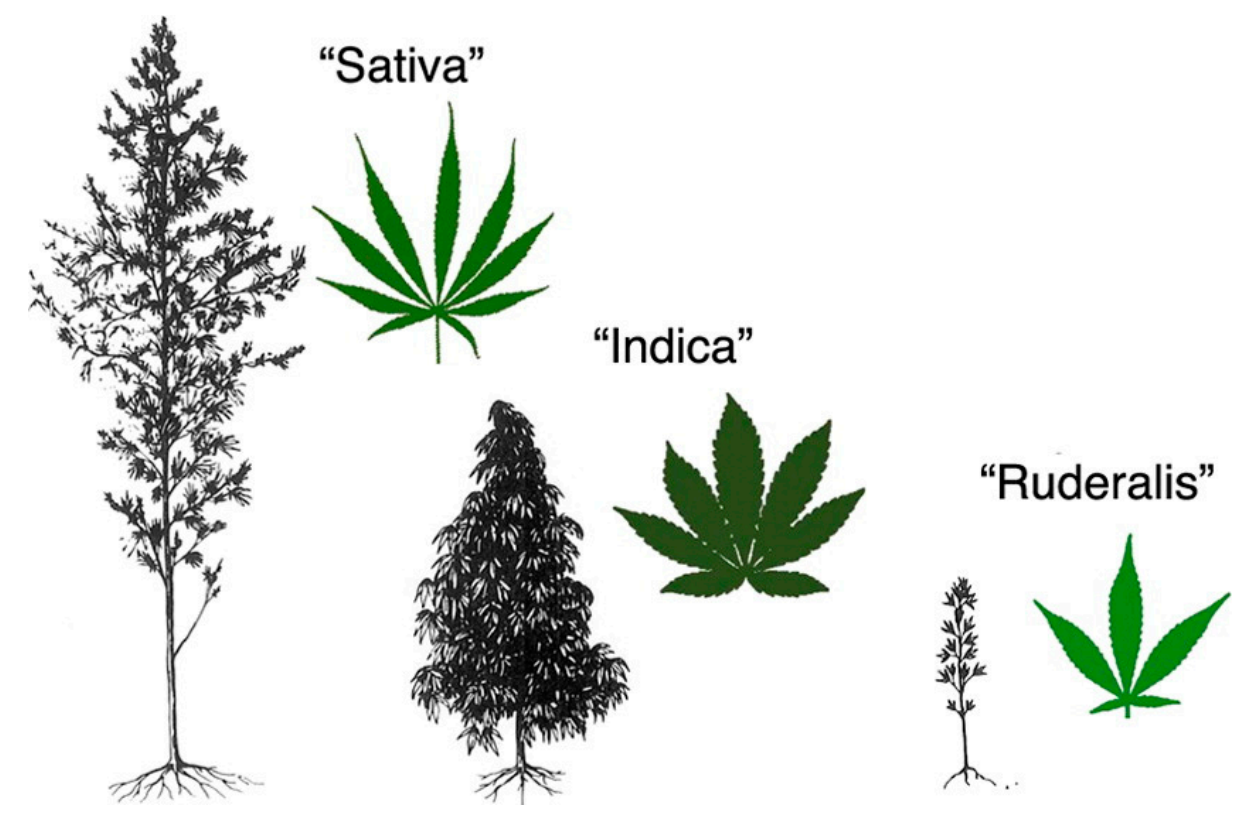

Figure 1. Morphological differences among varieties of Cannabis sativa species, image from John M. McPartland. Cannabis and Cannabinoid Research. Dec 2018.203-212. http://doi.org/10.1089/can.2018. 0039 .

This plant contains over 500 chemical compounds, and more than 120 of them are terpenophenolics, also named phytocannabinoids $[5,6]$. The most studied, and therefore, the most known phytocannabinoids, are the psychoactive cannabinoid $\Delta^{9}$-tetrahydrocannabinol (THC) and the non-psychoactive cannabinoids: cannabidiol (CBD), cannabigerol (CBG), cannabichromene (CBC) and cannabidivarin (CBDV).

In the last forty years, phytocannabinoids have attracted considerable attention for their biological activity beneficial to human health, such as appetite-stimulant, antiemetic, anti-spasticity, analgesic, anti-inflammatory, and antitumoral properties. The mechanism responsible for the phytocannabinoids effects has been unknown until the discovery of the endocannabinoid system (ECS), in the early 1990s. 
The GI tract contains all the elements of the ECS (endocannabinoid ligands, synthesis and degradation enzymes of such ligands, and receptors), and thus, phytocannabinoids may powerfully impact on this system. With the increasing interest in the development of functional foods for a healthy life, there is hope that the non-psychoactive phytocannabinoids will find a place as nutraceuticals and food ingredients also for a healthy GI tract function.

In this narrative review, we will first look at the hemp plant as a possible source of new functional food ingredients and nutraceuticals that might be eventually useful to treat or even prevent GI conditions. Then, we will briefly describe the ECS and will summarize the general pharmacology of phytocannabinoids, which are present at different proportions in the different Cannabis sativa varieties. Finally, we will revise the available data showing that non-psychoactive phytocannabinoids, particularly CBD, may be useful to treat different disorders and diseases of the GI tract.

\section{Use of Hemp and Non-Psychoactive Phytocannabinoids as Nutraceuticals and Food Ingredients}

The Cannabis sativa edibles industry will be a combination of the food and the pharmaceutical industries. According to the Agricultural Marketing Act of 1946, hemp is defined as "the plant Cannabis sativa and any part of that plant, including the seeds thereof and all derivatives, extracts, cannabinoids, isomers, acids, salts, and salts of isomers, whether growing or not, with a THC concentration of not more than 0.3 percent on a dry weight basis" [7]. The cultivation and consumption of hemp seeds with low $(<0.3 \%)$ THC levels has been recently legalized in Australia, Canada and the United States, and there is a growing interest in hemp seed, due to its nutritional value [8]. Breeding of different Cannabis sativa varieties for low THC levels has been a main target in hemp breeding, and levels below $0.2 \%$ THC have been reached for some cultivars. Regulations that allowed a THC content of only $0.2 \%$ were implemented in the European Union in 2001. Since then, a further and stable reduction of THC has gained importance as a breeding goal [9]. However, further research is required to ensure the quality, safety and beneficial properties of hemp food products.

The taxonomic organization of the genus Cannabis has been described above (see Section 1). Here we will concentrate on describing the features that make this plant attractive for the development of new nutraceuticals and food ingredients that might be useful for a healthy life, in general, and a healthy GI tract function, in particular.

Figure 2 shows the different anatomic parts of the hemp plant and the presence of nutrients and bioactive compounds in each part. Hemp seeds have been studied extensively in the past, but little is known on the composition and functional characteristics of the other anatomic parts of the hemp plant. More recently, the nutritional composition of the leaves and stem of Cannabis sativa have been described [10]. The major component present in the stem was fiber (23.14\%) followed by protein, fat and ash (Figure 2) [11]. The leaf showed a lipid content of 19.97\%. The crude protein content in the leaf was $23.78 \%$, while the crude fiber was $18.95 \%$, and the ash content was $11.18 \%$ [11]. These authors also reported the amino acid profile of the different parts of the plant and nine of the ten essential amino acids (lysine, histidine, arginine, threonine, valine, methionine, isoleucine, leucine and phenylalanine) were found in the leaves of $C$. sativa. The amino acid profile of $C$. sativa leaves is comparable in amino acid content to that from hemp seed and even egg white and soybeans [11].

The most abundant bioactive compounds found in hemp are $\Delta^{9}$-tetrahydrocannabinolic acid (THCA), cannabidiolic acid (CBDA) and cannabinolic acid (CBNA), followed by cannabigerolic acid (CBGA), cannabichromenic acid (CBCA) and cannabinodiolic acid (CBNDA) [12]. Phytocannabinoids accumulate in female flowers and in most aerial parts, but they have also been detected in low quantity in other parts of the plant (Figure 2). Generally, the concentration of these compounds depends on tissue type, age, variety, growth conditions (nutrition, humidity, light level), harvest time and storage conditions [12]. Cannabinoids in leaves have been shown to decrease with age, and along the stem axis, with the highest levels observed in the leaves of the uppermost nodes [13]. 


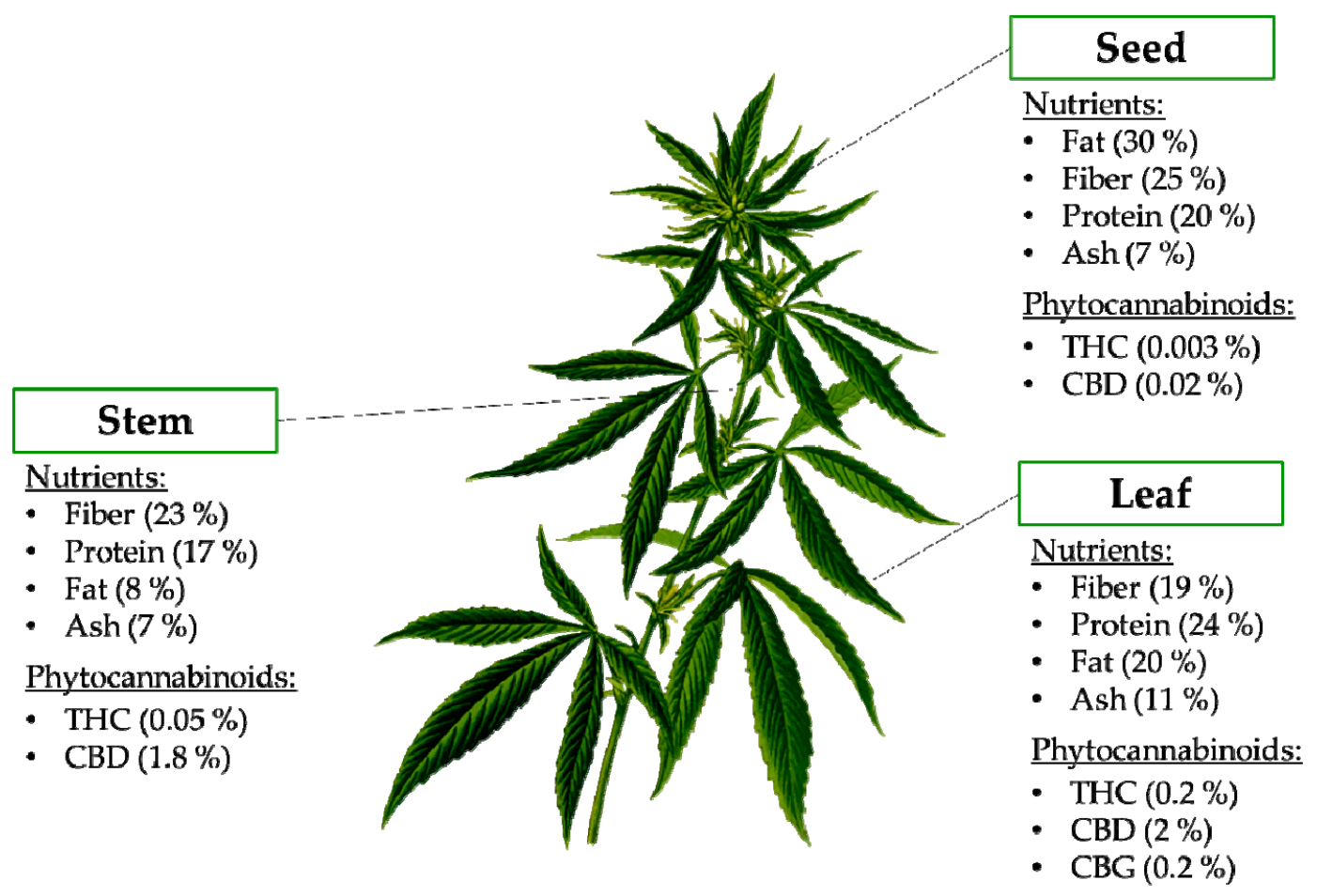

Figure 2. Nutritional composition and phytocannabinoids present in the different anatomic parts of the hemp plant. Abbreviations: CBD, cannabidiol; CBG, cannabigerol; THC, $\Delta^{9}$-tetrahydrocannabinol.

Since the consumption of hemp seeds has been legalized in some countries, their nutritional composition has been deeply studied. Hemp protein is mainly composed of globulin and albumin, and is characterized for its exceptionally high level of arginine and glutamic acid [8]. According to the FoodData Central database of the United States Department of Agriculture (USDA), hemp seed is composed of approximately $30-50 \%$ oil, of which $80 \%$ corresponds to unsaturated fatty acids. Hemp seed oil is composed of essential fatty acids, such as linoleic acid, alpha-linolenic acid and oleic acid [8]. Compared to other plant oils, hemp seed oil has the highest proportion of polyunsaturated fatty acids, which have the potential to reduce the risk of cardiovascular diseases, cancer, rheumatoid arthritis, hypertension, inflammatory and autoimmune diseases $[8,14,15]$. The omega- 6 to omega- 3 ratio (n6/n3) in hemp seed oil is normally between 2:1 and 3:1, which is considered to be optimal for human health [14]. In addition, hemp seed also contains both soluble and insoluble dietary fiber at a ratio about 20:80 [14]. Specifically, the insoluble dietary fiber of hemp seed is composed of cellulose $(46 \%)$, lignin (31\%) and hemicellulose (22\%) [15].

The whole hemp plant is a source of fibers, oil and bioactive compounds, and therefore, it is a good candidate to be used for human nutrition. The main limitation of using hemp for human consumption is the content of the psychoactive cannabinoid THC. Its precursor THCA is thermally unstable and can be decarboxylated when exposed to light or heat [16]. The transformation of THCA into THC could occur during food storage and processing affecting food safety. Therefore, the selection of THC-free and low THCA species is of great interest to ensure the safety of hemp-based products. However, in many cases, the amounts of THC detected in products that are marketed today are greater than expected when using certified species with levels of this compound within the established $(<0.2 \%)$ for its production for food consumption. Specific advanced analytical methods should be implemented to avoid the decarboxylation of THCA when quantifying THC. There is much criticism around the use of gas chromatography for cannabinoid analysis, since the high temperature of both injector and detector lead to decarboxylation of cannabinoid acids if not previously derivatized [17].

Hemp and its derivatives can be used as nutraceuticals or as food ingredients enriched in nutrients and non-nutrient bioactive compounds. Since Cannabis has a particular composition in nutrients and 
bioactive compounds, the exploitation of this plant in human nutrition is a priority research line at a global level. In 1989, Dr. Stephen DeFelice defined the term nutraceutical as "a substance that is a food or part of a food that provides medical and/or health benefits, including the prevention and treatment of disease" generally sold in medicinal forms (pills or tablets) not usually associated with foods [18]. This term is often interchanged with "functional food" in the scientific literature [19]. The European Commission Concerted Action on Functional Food Science in Europe (FUFOSE) defines functional foods as "a food, which beneficially affects one or more target functions in the body, beyond adequate nutritional effects, in a way that is relevant to either an improved state of health and well-being and/or reduction of risk of disease". A functional food can be a natural food or a food to which a component has been added or removed by technological or biotechnological means, and it must demonstrate their effects in amounts that can normally be expected to be consumed in the diet [20].

Hemp and hemp-derived ingredients can be used as a source of nutrients and bioactive compounds with potential health claims. Due to the legalization to cultivate low-THC hemp, an increasing number of hemp seed food products have been developed by researchers and manufacturers. There is a wide variety of food products in which cannabinoid extracts have been added, such as beverages (dairy and non-dairy), breakfast cereals, cookies, brownies, vegan burgers and sausages, and even more recently, beer, wine, hemp-infused milks, barley-based sodas, health beneficial-honeys, and fortified sports products (Table 1) [21]. To date, 680 branded food products containing hemp seed derivatives in the form of oil, extract, flour or powder, are registered in the FoodData Central database of the USDA [22]. Any of these products consumed in the USA must not contain more than $0.3 \%$ THC to be legal by US government regulations [21].

Table 1. Different uses of hemp seed as a food ingredient. Data obtained from FoodData Central database.

\begin{tabular}{ccc}
\hline Type of Ingredient & Type of Food & Number of Products \\
\hline Hemp seed & Seeds & 56 \\
& Chocolate & 13 \\
& Cereal & 80 \\
& Bars and snacks & 178 \\
& Bakery products & 37 \\
Hemp protein extract & Beverage & 52 \\
& Dressings, butter & 51 \\
& Prepared food & 24 \\
& Yogurt, cheese, ice-cream (vegan) & 13 \\
Hemp oil & Beverage & 78 \\
& Bars and snacks & 40 \\
Hemp flour & Powder & 24 \\
& Capsules & 1 \\
& Oil & 9 \\
& Beverage & 7 \\
& Pasta & 2 \\
& Veggie burger or sausage & 12 \\
\hline
\end{tabular}

In Europe, CBD food products that were legally on the market prior to January 2018 can continue to be sold as long as an application for novel food approved status is submitted. In the European Union (EU), the cultivation of Cannabis sativa varieties is permitted provided they are registered in the EU's 'Common Catalogue of Varieties of Agricultural Plant Species', and the THC content does not exceed $0.2 \%$. Some products derived from the Cannabis sativa plant or plant parts, such as seeds, seed oil, hemp seed flour, and defatted hemp seed, have a history of consumption in the EU [23]. However, any other product derived from hemp different from the seeds is considered novel and needs to undergo European Food Safety Authority's (EFSA) authorization procedure according to the Regulation (EU) 2015/2283 before it could be introduced into the European food market. A novel food is defined as 
"food that was not used for human consumption to a significant degree within the Union before 15 May 1997, irrespective of the dates of accession of the Member States to the Union" [24]. Currently, only one application can be found on the European Commission Summary of the ongoing applications web page. The application for the authorization of trans-CBD contains safety and toxicological information and toxicity reviews, which include acute and long term toxicity studies in animals, and tolerance studies in humans [25].

In food, there are many potential applications for the use of hemp-based ingredients that have been discussed in the previous paragraphs. From a legal perspective, the future is still uncertain, and the regulation of hemp consumption is expected to be "a headache" during 2020 and the following years. New varieties with less THC and THCA content and non-thermal food processing methods are needed for the use of hemp as a novel food ingredient. There is the need to obtain the necessary and sufficient scientific evidence to certify the safety and to assign nutrition and health claims of food containing hemp-based ingredients. Further research is required to ensure the quality, safety and beneficial properties of hemp food products. Finally, more research regarding the health-promoting properties of pure and combined bioactive compounds in hemp is also needed.

\section{The Endogenous Cannabinoid System}

The ECS is a cell-signaling system, comprising endogenous ligands (endocannabinoids), cannabinoid receptors (CB1 and CB2) and proteins involved in endocannabinoid synthesis and inactivation [26,27].

Cannabinoid receptors (CB1 and CB2) are G protein-coupled receptors (GPR) containing seven transmembrane spanning domains. The CB1 receptor, identified in the brain in 1988 [28], is predominantly localized in the neurons of the central nervous system (CNS) on presynaptic terminals, where it mediates retrograde signaling of endocannabinoids. To a lesser extent, CB1 is also localized in microglia, astrocytes, and oligodendrocytes of the CNS [29,30]. In addition to CNS, CB1 is also expressed in the peripheral nervous system (PNS) and peripheral tissues. In the PNS, CB1 is localized in sympathetic nerve terminals, and more importantly, in primary sensory neurons where it affects nociception from afferent nerve fibers [31]. In the GI tract, CB1 is expressed in the enteric nervous system (ENS) and in non-neural cells where it regulates the GI functions (i.e., motility, secretion and permeability) and energy balance [32]. In the cardiovascular system, CB1 is expressed in specific restricted regions within cardiac myocytes, where it seems to be involved in cardiovascular dysfunctions [33,34]. The CB1 receptor is also localized in the liver, lung, bone, skin, eye, adipose tissue and skeletal muscle.

The CB2 receptor was discovered and successfully cloned in 1993, and unlike CB1, it is primarily localized on immune cells and low expressed in the CNS [35,36]. Accumulated evidence has demonstrated the presence, although in low amount, of CB2 receptors in several peripheral tissues, including the GI tract, cardiovascular system, adipose tissue, liver, bone and the reproductive system [35].

At the cellular level, both the CB1 and CB2 receptors are localized in the cell membranes, although an intracellular localization has been reported [37]. Activation of cannabinoid receptors induces: (1) Inhibition of adenylyl cyclase activity, calcium channels and D-type potassium channels, (2) increase in the phosphorylation of mitogen-activated protein kinases, and (3) activation of A-type potassium channels [37].

The discovery of the cannabinoids receptors has led to the identification of endogenous ligands, called endocannabinoids, including anandamide (arachidonylethanolamide, AEA), 2-arachidonoylglycerol (2-AG), $N$-arachidonoyldopamine (NADA), noladin ether (2-arachidonoylglycerylether, 2-AGE) and virodhamine (O-arachidonoylethanolamine, O-AEA) [26]. However, until now, only AEA and 2-AG have been deeply studied. Although both endocannabinoids are synthetized on demand from the cell membrane phospholipids, they are synthesized, transported and inactivated differently (Figure 3) and possess a different affinity for the two cannabinoid receptors [26]. 


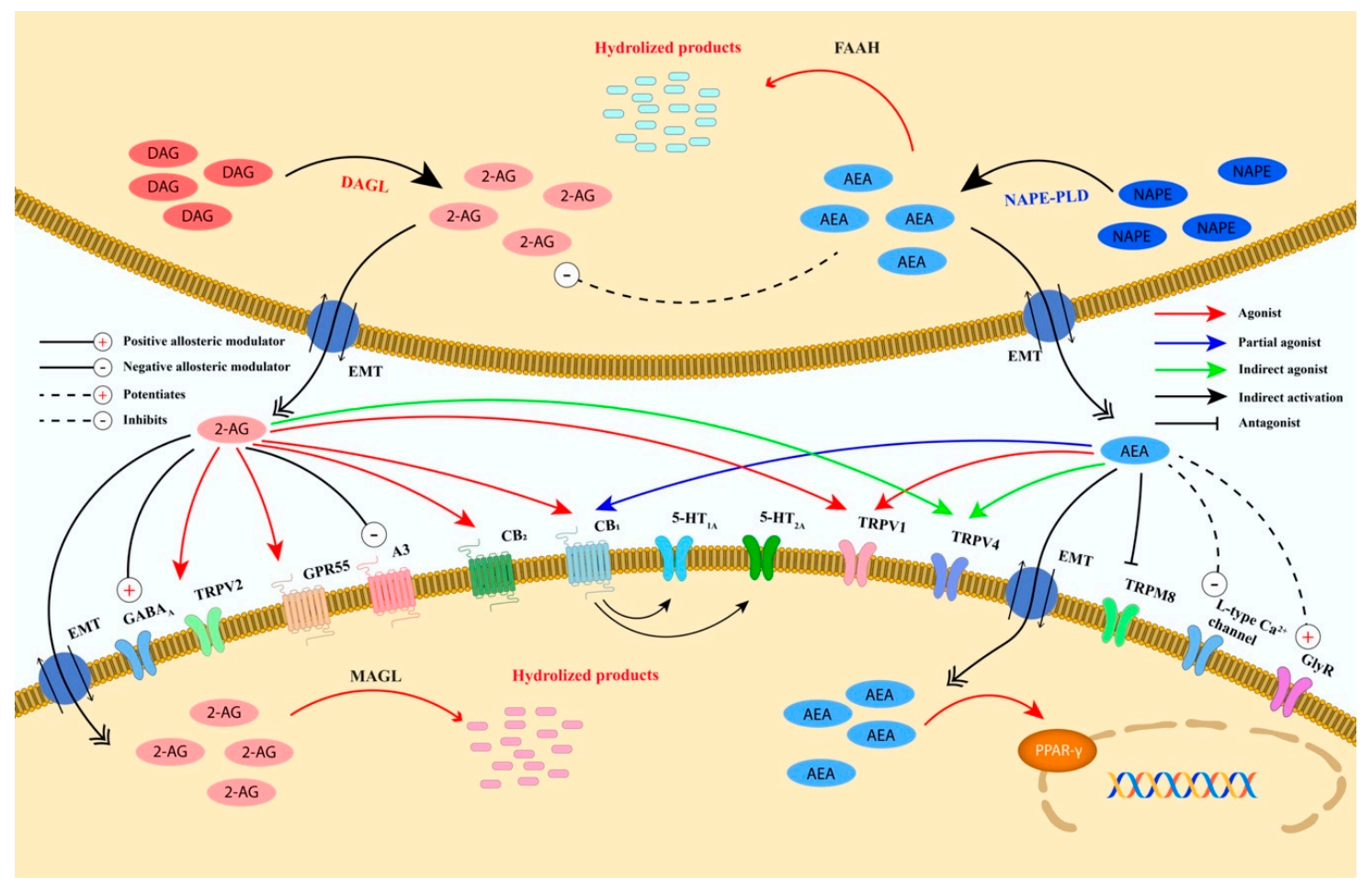

Figure 3. Schematic representation of the biosynthesis, degradation, and receptors' binding of AEA and 2-AG. Anandamide and 2-AG are postsynaptically biosynthesized from the membrane's phospholipids and degraded with different pathways and enzymes. AEA is mainly synthesized from NAPE by NAPE-PLD, whereas 2-AG is biosynthesized from DAG by DAGL- $\alpha$ and DAGL- $\beta$. The degradation of AEA is catalyzed by FAAH that is mainly expressed postsynaptically. 2-AG is degraded by MAGL that is expressed presynaptically and by two hydrolases named ABHD6 and ABHD12, expressed postsynaptically. Furthermore, AEA and 2-AG catabolism might also occur by the activity of other enzymes (e.g., NAAA, COX-2, and several LOX isoenzymes). AEA and 2-AG retrogradely activate presynaptic CB1. AEA is almost inactive on CB2, whereas 2-AG acts as a full agonist. In addition, AEA, directly or indirectly, also modulates the receptors/channels CB1, CB2, TRPV1 (at postsynaptic and presynaptic level), TRPV4, TRPM8, PPAR $\gamma, 5-\mathrm{HT}_{1 \mathrm{~A}}, 5 \mathrm{HT}_{2 \mathrm{~A}}$, L-type $\mathrm{Ca}^{2+}$ channel, GlyR and negatively regulates 2-AG biosynthesis. 2-AG, directly or indirectly, modulates the receptors/channels TRPV1, TRPV2, TRPV4, GPR55, A3 adenosine, $\mathrm{GABA}_{\mathrm{A}}, 5-\mathrm{HT}_{1 \mathrm{~A}}$, and $5 \mathrm{HT}_{2 \mathrm{~A}}$. The activation of CB1 by 2-AG suppresses either GABA or glutamate release. Abbreviations: ABDH6/12, $\alpha \beta$-hydrolase domain 6/12; AEA, anandamide; 2-AG, 2-arachidonoylglycerol; CB1, cannabinoid receptor 1; CB2, cannabinoid receptor 2; COX-2, cyclooxygenase-2; DAG, diacylglycerol; DAGL- $\alpha$ and DAGL- $\beta$, diacylglycerol lipase- $\alpha$ and $\beta$ isoforms; EMT, endocannabinoid membrane transporter; FAAH, fatty acid amide hydrolase; GABA, $\gamma$-aminobutyric acid; $\mathrm{GABA}_{\mathrm{A}}, \gamma$-aminobutyric acid type A receptor; GlyR, glycine receptor; GPR55, G protein-coupled receptor 55; 5- $\mathrm{HT}_{1 \mathrm{~A}}$, 5-hydroxytryptamine $1 \mathrm{~A}$ receptor; $5-\mathrm{HT}_{2 \mathrm{~A}}$, 5-hydroxytryptamine 2A receptor; LOX, lipoxygenase; MAGL, monoacylglycerol lipase; NAAA, $\mathrm{N}$-acylethanolamine hydrolyzing acid amidase; NAPE-PLD, N-acyl-phosphatidylethanolamine-specific phospholipase D; PPAR $\gamma$, peroxisome proliferator-activated receptor type- $\gamma$; TRPM8, transient receptor potential cation channel subfamily M member 8; TRPV2, transient receptor potential cation channel subfamily V member 2; TRPV4, transient receptor potential cation channel subfamily V member 4; TRPV1, transient receptor potential vanilloid type-1 channel.

AEA is biosynthesized from N-acyl-phosphatidylethanolamine (NAPE) by NAPE-specific phospholipase D (NAPE-PLD) whereas 2-AG is synthesized from diacylglycerol (DAG) by DAG lipase (DAGL) $\alpha$ or $\beta$ [26]. AEA and 2-AG are mainly inactivated by two enzymes, fatty acid amide hydrolase (FAAH) and monoacylglycerol lipase (MAGL), although other degradation enzymes/pathways have been identified [i.e., $\alpha / \beta$-hydrolase domain containing (ABHD) 6 and 12 (for $2-A G$ ), $N$-acylethanolamine 
acid amide hydrolase (NAAA) (for AEA), cyclooxygenase-2 (COX-2), 12-lipooxygenase (12-LOX), 15-LOX (for AEA and 2-AG)] [38]. Specifically, AEA is mainly hydrolyzed by FAAH into free arachidonic acid and ethanolamine, whereas MAGL catalyzes the degradation of 2-AG into arachidonic acid and glycerol (Figure 3).

AEA has been demonstrated to have both a high affinity for the CB1 receptor, where it acts as a partial agonist, and a low CB2 affinity [26]. Conversely, 2-AG has a moderate affinity for both receptors where it behaves as a full agonist [26].

In addition to CB1 and CB2 receptors, endocannabinoids have also been reported to modulate several other receptors and channels including transient receptor potential (TRP) channels and the G protein-coupled receptor (GPR) 55, GPR18, GPR119, $\gamma$-aminobutyric acid (GABA) A and glycine receptors [26] (Figure 3).

\section{Cannabis sativa and its Phytocannabinoids}

Considering the content of THC of Cannabis sativa, this species can be divided into two subspecies: C. sativa subsp. Sativa (THC $<0.3 \%$ ) and C. sativa subsp. Indica (THC $>0.3 \%$ ) [39]. C. sativa and C. indica can also be separated by morphology (C. sativa is taller with a fibrous stem, whereas $C$. indica is shorter with a woody stem, Figure 1), and by differences in their original geographic range (C. sativa in Europe and C. indica in Asia) [4].

\section{Psychoactive and Non-Psychoactive Phytocannabinoids Molecular Targets}

As mentioned above, more than 120 phytocannabinoids have been identified in the plant Cannabis sativa. Among these, the most studied are THC, CBD, CBG, CBC and CBDV (Table 2). These substances are present in the plant as their carboxylated version (i.e., tetrahydrocannabinolic acid (THCA), cannabidiolic acid (CBDA), cannabigerolic acid (CBGA), etc.). During the harvest, drying, and storage of Cannabis sativa or when heat via smoking, the carboxylated phytocannabinoids are decarboxylated, and therefore, converted into the corresponding chemically neutral version [40,41].

Table 2. Molecular targets of the most abundant phytocannabinoids in Cannabis sativa.

\begin{tabular}{|c|c|c|}
\hline \multicolumn{3}{|c|}{$\Delta^{9}$-TETRAHYDROCANNABINOL } \\
\hline Chemical structure & Molecular Targets & References \\
\hline & CB1 partial agonist & [42] \\
\hline & CB2 partial agonist & {$[42]$} \\
\hline & GPR55 agonist & [43] \\
\hline & GPR18 agonist & {$[44,45]$} \\
\hline & $5 \mathrm{HT}_{3 \mathrm{~A}}$ antagonist & {$[46]$} \\
\hline & PPAR $\gamma$ agonist & {$[47,48]$} \\
\hline & TRPA1 agonist & [49] \\
\hline & TRPV2 agonist & [50] \\
\hline $\mathrm{OH}$ & TRPV3 agonist & [51] \\
\hline & TRPV4 agonist & {$[51]$} \\
\hline & TRPM8 antagonist & [49] \\
\hline & $\mu$ and $\delta$ opioid allosteric modulator & {$[52,53]$} \\
\hline & GlyR $\alpha_{1}$ and $\alpha_{3}$ positive allosteric modulator & [54] \\
\hline & AEA uptake inhibition by targeting FABPs & {$[55-57]$} \\
\hline & Adenosine reuptake inhibitor & [58] \\
\hline
\end{tabular}


Table 2. Cont.

\begin{tabular}{|c|c|c|}
\hline \multicolumn{3}{|c|}{ CANNABIDIOL } \\
\hline Chemical structure & Molecular Targets & References \\
\hline & CB1 inverse agonist and negative allosteric modulator & {$[59,60]$} \\
\hline & CB2 partial agonist and negative allosteric modulator & {$[59,61]$} \\
\hline & GPR55 antagonist & [62] \\
\hline & GPR18 antagonist & [44] \\
\hline & GPR3 inverse agonist & {$[63]$} \\
\hline & GPR6 inverse agonist & [63] \\
\hline & GPR12 inverse agonist & {$[64]$} \\
\hline & $\mathrm{A}_{1 \mathrm{~A}}$ agonist & [65] \\
\hline & $5 \mathrm{HT} 1_{\mathrm{A}}$ agonist & [66] \\
\hline & $5 \mathrm{HT}_{2 \mathrm{~A}}$ partial agonist & {$[66]$} \\
\hline & $5 \mathrm{HT}_{3 \mathrm{~A}}$ antagonist & [67] \\
\hline & PPAR $\gamma$ agonist & {$[68]$} \\
\hline & TRPA1 agonist & [56] \\
\hline & TRPV1 agonist & {$[55,56]$} \\
\hline & TRPV2 agonist & {$[50]$} \\
\hline & TRPV3 agonist & [51] \\
\hline & TRPM8 antagonist & [56] \\
\hline & $\mathrm{GABA}_{\mathrm{A}}$ positive allosteric modulator & [69] \\
\hline & $\mu$ and $\delta$ opioid allosteric modulator & {$[52,53]$} \\
\hline & GlyR $\alpha_{1}$ and $\alpha_{3}$ positive allosteric modulator & {$[70,71]$} \\
\hline & AEA uptake inhibition by targeting FABPs & [55-57] \\
\hline & Adenosine reuptake inhibitor & [58] \\
\hline \multicolumn{3}{|c|}{ CANNABIGEROL } \\
\hline Chemical structure & Molecular Targets & References \\
\hline & CB1 weak partial agonist & {$[72]$} \\
\hline & CB2 weak partial agonist & {$[72,73]$} \\
\hline & GPR55 antagonist & [74] \\
\hline & $\alpha_{2}$-adrenoceptor agonist & [75] \\
\hline & $5 \mathrm{HT} 1_{\mathrm{A}}$ antagonist & [75] \\
\hline & TRPA1 agonist & {$[49,56]$} \\
\hline & TRPV1 agonist & {$[56]$} \\
\hline & TRPV2 agonist & [56] \\
\hline & TRPV4 antagonist & [51] \\
\hline $\mathrm{CH}_{3}$ & TRPM8 antagonist & {$[49,56]$} \\
\hline & Voltage-gated sodium channels $\mathrm{Na}_{\mathrm{V}}$ blocker & [76] \\
\hline & AEA uptake inhibitor & [56] \\
\hline & MAGL inhibitor & [56] \\
\hline \multicolumn{3}{|c|}{ CANNABICHROMENE } \\
\hline Chemical structure & Molecular Targets & References \\
\hline & CB2 agonist & [77] \\
\hline & TRPA1 agonist & {$[49,56]$} \\
\hline & TRPV1 agonist & [56] \\
\hline & TRPV3 agonist & [51] \\
\hline & TRPV4 agonist & [51] \\
\hline & TRPM8 weak antagonist & [56] \\
\hline & AEA uptake inhibitor & [56] \\
\hline & MAGL inhibitor & [56] \\
\hline
\end{tabular}


Table 2. Cont.

\begin{tabular}{|c|c|c|}
\hline \multicolumn{3}{|c|}{ CANNABIDIVARIN } \\
\hline Chemical structure & Molecular Targets & References \\
\hline & GPR55 antagonist & [74] \\
\hline & TRPA1 agonist & [56] \\
\hline & TRPV1 agonist & [56] \\
\hline & TRPV2 agonist & [56] \\
\hline & TRPV3 agonist & [51] \\
\hline & TRPV4 agonist & [51] \\
\hline & TRPM8 antagonist & [56] \\
\hline & DAGL inhibitor & [56] \\
\hline & AEA uptake inhibitor & [56] \\
\hline \multicolumn{3}{|c|}{ CANNABIDIOLIC ACID } \\
\hline Chemical structure & Molecular Targets & References \\
\hline & GPR55 antagonist & [74] \\
\hline & $5 \mathrm{HT}_{1 \mathrm{~A}}$ agonist (potentiation) & [78] \\
\hline & TRPA1 agonist & {$[49,56]$} \\
\hline & TRPV1 weak agonist & [56] \\
\hline & TRPM8 antagonist & {$[56]$} \\
\hline & NAAA inhibitor & [56] \\
\hline & DAGL inhibitor & [56] \\
\hline & AEA uptake inhibitor & [56] \\
\hline \multicolumn{3}{|c|}{ CANNABIGEROLIC ACID } \\
\hline Chemical structure & Molecular Targets & References \\
\hline & GPR55 inhibition & {$[74]$} \\
\hline & TRPA1 weak agonist & [56] \\
\hline & TRPV3 antagonist & [51] \\
\hline & TRPV4 antagonist & [51] \\
\hline & TRPM8 antagonist & [56] \\
\hline & AEA uptake inhibitor & [56] \\
\hline $\mathrm{CH}_{3}$ & DAGL inhibitor & [56] \\
\hline
\end{tabular}

See abbreviations at the end of the chapter.

THC, isolated in 1964, is the most abundant psychoactive cannabinoid in Cannabis sativa. In addition to the psychotropic effects (due to the activation of the CNS CB1 receptor), THC by acting on CNS CB1: (1) Induces drowsiness and impairment of short term memory; (2) reduces alertness, the accuracy of psychomotor task performance, motor coordination, muscle tone and pain perception; (3) exerts antinauseant and antiemetic effects; and (4) increases appetite [59,79]. Moreover, at low doses, THC induces mild euphoria, relaxation and reduces anxiety, whereas, at high doses, leads to dysphoria, sensory distortion, hallucinations, and increases anxiety. THC also exerts other numerous pharmacological effects that are mediated by either CB1 and/or CB2 receptor activation or other targets. Specifically, THC induces tachycardia, antispasticity and anti-convulsant effects, bronchodilatation, bronchial irritation, and ocular hypotonicity. In addition to CB1 and CB2 activation, THC can act as an agonist of the receptors/channels GPR55, GPR18, peroxisome proliferator-activated receptor gamma (PPAR $\gamma$ ), transient receptor potential (TRP) A1, TRPV2, TRPV3 and TRPV4, and as an antagonist of the receptors/channels TRPM8 and 5HT3A (see Table 2 for references). Moreover, THC is able to modulate orthosteric agonist affinity and/or efficacy of $\mu / \delta$ opioid receptors (negative allosteric modulator) and GlyR $\alpha 1 / \alpha 3$ receptors (positive allosteric modulator) [52-54]. Finally, this psychoactive phytocannabinoid is also able to increase AEA (inhibiting its uptake by competing with AEA for binding to fatty acid binding proteins, FABPs) and adenosine levels [57,58].

For its pharmacological effects, THC has been used to treat nausea and vomiting associated with cancer chemotherapy and to stimulate appetite in patients with acquired immunodeficiency 
syndrome (AIDS). THC has also been used to treat pain, spasticity in patients with multiple sclerosis, and glaucoma. However, the clinical use of THC is limited today, due to its psychoactive effects. Thus, in the last forty years, much attention has been paid to non-psychoactive phytocannabinoids, such as $\mathrm{CBD}, \mathrm{CBG}, \mathrm{CBC}$, and CBDV.

Although CBD was isolated from marijuana in 1940, interest in this compound started when it was shown that CBD was able to reduce the psychotropic effect of $\Delta^{9}$-THC $[80,81]$. Subsequently, it has been demonstrated that CBD possesses a wide spectrum of actions including neuroprotective, analgesic, anti-inflammatory, anti-epileptic, anxiolytic and antipsychotic effects [82,83]. Moreover, CBD improves sleep disorders and induces mood stabilization [84-86]. CBD effects are mediated by its action on multiple molecular targets $[83,87]$. CBD has been demonstrated to have a low affinity for both CB1 and CB2 receptors where mainly acts as a negative allosteric modulator. CBD acts as an agonist of the receptors/channels TRPA1, TRPV1, TRPV2, TRPV3, PPAR $\gamma, 5-\mathrm{HT} 1 \mathrm{~A}$, and A1A, and as an antagonist of the receptors GPR55, GPR18, and 5HT3A (see Table 2 for references). CBD is an inverse agonist of the receptors GPR3, GPR6, and GPR12 [63,64]. CBD is an allosteric modulator of $\mu$ - and $\partial$-opioid receptors [52,53], GABAA [69] and GlyR $\alpha 1 / \alpha 3$ receptors [71]. CBD functions as an anandamide reuptake and breakdown inhibitor by targeting FABPs [57]. Finally, recently it has been demonstrated that, in addition to the negative allosteric effect on the CB1 receptor, CBD affects the $\Delta^{9}$-THC cognitive impairment in an adenosine A2A receptor (A2AR)-dependent manner [88].

Clinical studies have demonstrated that CBD has a good safety profile, and it is effective in the drug-resistant seizure in patients with severe rare forms of epilepsy [89]. In June 2018, CBD was approved by the Food and Drug Administration (FDA), with the trade name of Epidiolex, as an anti-epileptic drug for patients (2 years of age and older) with Dravet or Lennox-Gastaut syndromes. By contrast, clinical evidence regarding the efficacy of $C B D$ in psychiatric disorders is preliminary. Moreover, encouraging preliminary evidence also exists on the efficacy of CBD in patients with autism [90]. Specifically, CBD seems able to reduce aggression, anxiety and hyperactivity in patients with autism. In several countries, Sative ${ }^{\circledR}$, an oromucosal spray containing an equimolecular combination of $\Delta^{9}$-tetrahydrocannabinol-botanical drug substance ( $\Delta^{9}$-THC-BDS) and cannabidiol-botanical drug substance (CBD-BDS), has been approved for the use of neuropathic pain, due to multiple sclerosis.

Another abundant non-psychotropic cannabinoid in Cannabis sativa is CBG. Pharmacodynamic studies have shown that $C B G$ targets components of the ECS, as well as a range of other receptors and ion channels. CBG displays a weak affinity for $\mathrm{CB} 1$ and $\mathrm{CB} 2$ receptors where it acts as a partial agonist. In addition, CBG acts as an agonist of $\alpha 2$-adrenoceptor, TRPA1, TRPV1, and TRPV2 receptors, and as an antagonist of TRPM8, TRPV4 and 5HT1A receptors (see Table 2 for references). Moreover, CBG, as CBD, inhibits AEA uptake, MAGL and lysophosphatidylinositol (LPI)-induced GPR55 signaling (see Table 2 for references).

CBC, discovered in 1966, acts as an agonist of CB2 receptors, TRPA1 (it seems to be the most potent TRPA1 agonist among phytocannabinoids), TRPV3, TRPV4 channels and an antagonist of TRPM8 channels (see Table 2 for references). Similar to CBG, CBC increases AEA (inhibiting its uptake) and MAGL levels (see Table 2 for references).

CBDV has been reported to have a low affinity for $\mathrm{CB} 1$ and $\mathrm{CB} 2$ receptors. CBDV acts as an agonist of TRPA1, TRPV1, TRPV2, TRPV3 and TRPV4 channels, and as an antagonist of TRPM8 channels (see Table 2 for references). Moreover, CBDV inhibits AEA uptake, DAGL and LPI-induced activation of GPR55. CBDV exert anti-convulsant [91], neuroprotective properties [92], and rescues cognitive deficits [93]. Today, CBDV is under clinical investigation for epilepsy treatment and autism spectrum disorders (ClinicalTrials.gov Identifier: NCT02369471, NCT03202303) [94].

\section{Cannabidiol and Other Non-Psychoactive Phytocannabinoids for Gastrointestinal Health}

Receptors and ligands of the ECS are widely expressed in relevant areas and systems, both within and outside the GI tract, related to the control of GI functions. As mentioned above, all the components of the ECS are present within the GI tract [95-98]. Consistent with these data, 
numerous reports have identified an important role for cannabinoids, including non-psychoactive phytocannabinoids, in the control of GI functions in health and disease states. Available experimental data show that the ECS is implicated in the control of motility, secretion, epithelial barrier function and viscerosensitivity, being a key component in the maintenance of GI homeostasis and a significant player in several pathophysiological states implicating a neuro-immuno-endocrine dysregulation of the GI tract (Table 3) $[96,97,99-108]$.

Table 3. Main locations and functions of different components of the endocannabinoid system (ECS) within the gastrointestinal (GI) tract.

\begin{tabular}{|c|c|c|}
\hline \multicolumn{3}{|c|}{ RECEPTORS } \\
\hline COMPONENT & LOCATION & FUNCTION \\
\hline CB1 (binds AEA, 2-AG) & $\begin{array}{l}\text { ENS: cholinergic neurons } \\
\text { Mucosa: epithelial and plasma cells } \\
\text { Vascular smooth muscle cells } \\
\text { Lamina propria: macrophages and } \\
\text { plasma cells }\end{array}$ & $\begin{array}{l}\text { Reduces GI motility and secretion } \\
\text { Modulates immune function }\end{array}$ \\
\hline CB2 (binds AEA, 2-AG) & $\begin{array}{l}\text { ENS (under inflammatory conditions) } \\
\text { Mucosa: epithelial cells, macrophages > } \\
\text { plasma cells } \\
\text { Lamina propria: macrophages and } \\
\text { plasma cells }\end{array}$ & $\begin{array}{l}\text { Reduces GI motility and secretion } \\
\text { Modulates immune function }\end{array}$ \\
\hline $\begin{array}{l}\text { TRPV1 (binds AEA > } \\
\text { OEA) }\end{array}$ & $\begin{array}{l}\text { Extrinsic afferent fibers, running through } \\
\text { the muscle layers } \\
\text { Immune cells adjacent to blood vessels. }\end{array}$ & $\begin{array}{l}\text { Visceral hypersensitivity signaling } \\
\text { Increase in intestinal contractility } \\
\text { (under inflammatory conditions) }\end{array}$ \\
\hline $\begin{array}{l}\text { PPAR- } \alpha \text { (binds AEA, } \\
\text { 2-AG, OEA, PEA, others) }\end{array}$ & $\begin{array}{l}\text { Enterocytes of the small intestine } \\
\text { ENS } \\
\text { Vagal afferent fibers } \\
\text { Enteric glial cells }\end{array}$ & \\
\hline GPR55 (binds PEA) & $\begin{array}{l}\text { Epithelial cells and ENS of the small } \\
\text { intestine }\end{array}$ & \\
\hline $\begin{array}{l}\text { GPR119 (binds OEA, } \\
\text { PEA > AEA) }\end{array}$ & Villi: enteroendocrine L cells & Regulates the release of GLP-1 \\
\hline \multicolumn{3}{|c|}{ METABOLIC ENZYMES } \\
\hline COMPONENT & LOCATION & FUNCTION \\
\hline FAAH & $\begin{array}{l}\text { Cells of the myenteric plexus in stomach } \\
\text { and intestine }\end{array}$ & Degrades AEA, PEA, OEA \\
\hline MAGL & $\begin{array}{l}\text { Nerve cells and fibers in the muscle layers } \\
\text { and mucosa of duodenum, ileum and colon }\end{array}$ & $\begin{array}{l}\text { Degrades } 2-A G \\
\text { Activity decreases from proximal } \\
\text { to distal locations }\end{array}$ \\
\hline \multicolumn{3}{|c|}{ LIGANDS } \\
\hline COMPONENT & LOCATION & FUNCTION \\
\hline AEA & Higher levels in colon than in ileum & $\begin{array}{l}\text { Increased levels in IBD, celiac } \\
\text { disease, diverticulitis, CRC }\end{array}$ \\
\hline 2-AG & Higher levels in ileum than in colon & Increased levels in CRC \\
\hline
\end{tabular}

Within the GI tract, the ECS has, overall, an inhibitory role. Indeed, direct or indirect activation of cannabinoid receptors reduces gastric and intestinal motility, and several motility-related parameters [97,99,106,107,109-111]; inhibits gastric and intestinal secretion [97,101,112]; modulates visceral sensitivity, reducing pain sensations $[97,100,104,111,113]$, and reduces the activity of the local immune system, lowering inflammatory responses [97,101,114]. 
Interestingly, although the effects of the ECS can be observed under physiological conditions, it is under pathophysiological states when the system probably displays its full significance. Under pathophysiological conditions, many of the components of the ECS are upregulated. In particular, increased expression of cannabinoid receptors and/or enhanced endocannabinoid levels, due to changes in the expression and activity of the enzymatic machinery implicated in the synthesis and metabolism of endocannabionids, have been observed (see also Table 2) [95,114]. Therefore, the system, as a whole, displays higher activity, including the manifestation of modulatory/regulatory functions not evidenced under physiological conditions [95,114]. Taking into account these observations, the potential therapeutic use of cannabinoids for the treatment of GI-related disorders have been widely explored $[97,99-101,105,106]$. However, the central psychoactive effects (such as catalepsy, hypothermia, hyperphagia, anxiety, panic attacks, paranoia and cognitive impairment) of the main active component of Cannabis sativa, THC, has limited its clinical use [115]. In this context, non-psychotropic phytocannabinoids, with similar pharmacological properties as THC, but devoid of the undesired central psychoactive effects, used as classical drugs or as herbal nutraceuticals, might represent an interesting alternative $[116,117]$. Here, we will focus on recent evidence related to the effects and use of $\mathrm{CBD}$, and other non-psychoactive phytocannabinoids, for the prevention and treatment of GI diseases.

\subsection{Role in Irritable Bowel Syndrome}

Irritable bowel syndrome (IBS) is a multifactorial, highly prevalent functional GI disorder (10-20\% in the developed world), characterized by the presence of functional alterations in the absence of evident underlying organic causes. Main alterations observed include GI motility disturbances [with predominant constipation (IBS-C), predominant diarrhea (IBS-D) or mixed bowel habits (IBS-M)], abnormal visceral sensitivity (hypersensitivity), altered epithelial barrier function (leaky gut), dysbiosis and disruptions of the brain-gut axis leading, mainly, to abnormalities in the processing of visceral afferent inputs [118-122]. Because of these characteristics, modulation of the ECS might be beneficial for IBS patients. Overall, cannabinoid-based therapies for functional GI disorders are focused predominantly on pain relief and modulation of intestinal motility.

Early reports indicated that CBD did not affect intestinal motility (gastric emptying, small intestinal transit and defecation) when tested in normal, healthy, animals, compared with other natural cannabinoids (such as $\Delta^{8}$-THC or $\Delta^{9}$-THC) that elicited inhibitory effects [123-127]. These observations were further confirmed using pure CBD and a cannabis extract with high content in CBD. While pure CBD had no effects on healthy animals, extracts with high content in CBD had weak inhibitory effects, likely due to the presence of other bioactive substances (such as THC and THC-related molecules) [128]. Similar lack of effects was also observed, in physiological conditions, for the non-psychoactive phytocannabinoid CBC [126], while cannabinol (CBN) showed only weak inhibitory effects on GI transit compared to other cannabinoids $[129,130]$. However, when tested in states of altered motility, particularly in states of hypermotility, either CBD, CBN or CBC exhibited significant modulatory effects. For instance, in the model of croton oil-induced intestinal irritation in mice, which occurs with increased intestinal motility (i.e., a reduction in transit time), CBN [130], CBD $[127,131]$ and CBC [126] completely normalized intestinal transit. Interestingly, similar positive effects were also observed for CBD in lipopolysaccharide (LPS)-induced intestinal inflammation and hypomotility [132]. Altogether, these observations agree with the view that the ECS exhibits its full activity not in physiological conditions but under pathophysiological states [95,114]. Moreover, they indicate a potential for non-psychotropic phytocannabinoids, at least as it relates to CBD, CBN or CBC, on the treatment of IBS-associated dysmotility, particularly for patients with the diarrhea predominant (IBS-D) or the mixed bowel habits (IBS-M) forms of the disease, as already suggested for the psychoactive cannabinoid dronabinol $[133,134]$. Because of the inflammatory component associated with some of the animal models used (LPS- and croton oil-induced dysmotility), these 
observations, although discussed here, might also bear interest for inflammatory disorders of the gut (see Section 5.2).

Abdominal pain associated with the sensitization of visceral sensory afferents and/or the derangement of sensory processing along the brain-gut axis is a key component of IBS [120]. Preclinical evidence, based on the colorectal distension model in rats and mice and the writhing test in mice, indicated that cannabinoid receptors, located in the CNS and/or at peripheral sites, may be involved in visceral pain and the development of visceral hypersensitivity [111,113,135-142]. Of note, the antinociceptive effects of cannabinoids were enhanced during inflammation [136,137], further supporting a role for the ECS in the development of visceral hypersensitivity and the therapeutic potential for the treatment of abdominal/visceral pain in IBS and other gut disorders, such as chronic constipation or inflammatory disorders. At a pre-clinical level, so far, only two studies have addressed the efficacy of phytocannabinoids modulating visceral pain, with some conflicting results. An early report showed that the non-psychotropic phytocannabinoids CBD and CBG showed significant analgesic activity in the writhing test in mice, although with lower efficacy than the psychoactive $\Delta^{1}$-THC [135]. On the other hand, CBN was inactive [135]. Lately, also using the writhing test model in mice, Booker et al. showed that only THC and CBN were able to elicit antinociceptive effects, through a CB1-dependent mechanism [138]. However, CBN exhibited a significantly lower potency than THC, per the differences in their relative binding affinity for CB1 receptors $\left(\mathrm{K}_{\mathrm{i}}\right.$; THC: $47.7 \mathrm{nM}$; CBN: $129.3 \mathrm{nM}$ ) [138]. Besides CBN, other non-psychotropic phytocannabinoids tested, namely CBD and CBC, did not manifest any analgesic effect in this model [138]. Although with some discrepancies, these reports suggest a potential therapeutic value for CBN, CBD, and CBG modulating visceral nociception. However, more research is needed to determine their effects in other visceral pain models (namely colorectal distension).

Despite the promising preclinical data, the efficacy of cannabinoids modulating IBS-associated abdominal pain has been difficult to prove in a clinical context, at least as it relates to the use of tetrahydrocannabinols [THC and dronabinol] $[133,143]$. This is not exclusive to IBS, since a lack of modulatory effects was also observed in patients with chronic abdominal pain [144] or post-operative abdominal pain [145]. On the other hand, no clinical studies addressing the modulation of visceral pain have been performed with non-psychotropic phytocannabinoids. According to the clinical trials register (https://clinicaltrials.gov; accessed 03/22/2020), a trial was started in 2016 assessing the effects of a CBD-containing chewing gum (CanChew $\left.{ }^{\circledR}\right)$ on IBS, having as a primary outcome changes in pain (ClinicalTrials.gov Identifier: NCT03003260). However, no additional information is available. Overall, this indicates that cannabinoids, per se, may be of little usefulness to reduce visceral hypersensitivity in IBS patients (or other GI conditions presenting abdominal/visceral pain). However, combinations with other pain modulatory agents, such as opioids, is regarded as an interesting alternative approach.

\subsection{Role in Inflammatory Bowel Disease}

Inflammatory bowel diseases (IBD), including Crohn's disease (CD) and ulcerative colitis (UC), is a multifactorial, chronic immune-mediated disease of the GI tract that results from a complex interaction between environmental, genetic and epigenetic risk factors that cause an inappropriate mucosal immune response leading to intestinal inflammation. IBD is characterized by periods of inflammatory flares, quiescence, and relapse, which places a substantial psychologic, emotional, and symptomatic burden on affected individuals $[146,147]$. The current therapeutic goals in managing IBD are reduction of inflammation, elimination of symptoms (mainly abdominal pain, fecal bleeding, diarrhea and weight loss), improvement in quality of life, and the prevention of complications [146,147]. Although the pathophysiology of the disease is not completely understood, knowledge of some of the underlying immunopathological mechanisms has led to the development of several effective therapies, used in the induction and maintenance of remission of disease activity [148,149]. Current therapies, however, are not effective in all patients, and patients that do respond often lose response over time; moreover, in many cases, symptoms persist even when inflammation is controlled and in remission. 
In addition, some patients develop adverse events that necessitate treatment discontinuation [150]. Therefore, IBD patients often turn to complementary medications, including various forms of cannabis, to combat symptoms related to their disease $[2,151,152]$.

Patients have reported using cannabis to relieve symptoms of abdominal pain, nausea, diarrhea and anorexia, as well as to improve mood and quality of life [152-155]. However, the evidence supporting the efficacy of cannabis in IBD is limited, and clinical guidelines and recommendations to assist physicians remain inadequate. Moreover, the long-term safety profile of cannabis in patients with IBD has not been established and remains a matter of concern [151,152]. In this context, non-psychotropic phytocannabinoids may be a valid and safe adjunct to medications in controlling inflammation, as well as improving symptomatology and quality of life. Therapeutic use of non-psychotropic phytocannabinoids in IBD is justified by their multiple modulatory roles within the GI tract, particularly affecting the activity of the local immune system (affecting cytokine, immunoglobulin production, and immune cell migration), but also because of their effects on motility and sensation (as discussed above for IBS) [156].

The immunomodulatory and anti-inflammatory actions of cannabinoids have been demonstrated in several experimental rodent models of intestinal inflammation [101,106,114,157,158]. Briefly, preclinical evidence shows: (1) Immunosuppressive effects derived from the impairment of both cellular and humoral immunity by reducing inflammatory cell recruitment, inducing $\mathrm{T}$ cell apoptosis and suppressing the production of numerous pro-inflammatory cytokines and chemokines [101,159]; (2) an increase in wound healing, leading to the restoration of intestinal epithelial barrier function [160]; (3) inhibition of GI motility and secretion leading to the reduction of diarrhea $[99,110,129,130,161,162]$ (see also comments related to IBS); and (4) a reduction of visceral hypersensitivity and abdominal pain (see comments related to IBS). In general, these actions inhibited the development of colitis and reduced the already established inflammation.

As it relates, specifically, to non-psychotropic phytocannabinoids, most of the studies performed have explored the anti-inflammatory actions of CBD [156], with only a few studies assessing the effects of other compounds, namely CBG, CBC, and CBDV (see Table 4). The anti-inflammatory effects of other non-psychotropic phytocannabinoids have not been studied so far.

Cannabidiol shows potent anti-inflammatory actions in different models of intestinal inflammation in mice and rats (dinitrobenzene sulfonic acid- [DNBS-], trinitrobenzene sulfonic acid- [TNBS-] and LPS-induced inflammation). In general, local or systemic administration of CBD resulted in a dose-related amelioration of disease parameters, reduction of structural damage and contention of inflammation-associated up-regulation of different cytokines, chemokines and markers of oxidative stress [131,132,156,163-166]. Moreover, some of these effects were also reproduced in in vitro conditions. For instance, CBD reduced the production of reactive oxygen species (ROS) and lipid peroxidation in Caco- 2 cells cultures [166], and counteracted LPS/interferon gamma (IFN $\gamma$ )-induced inflammatory-like responses in cultured human-derived colonic biopsies of UC patients [163]. Similar to that reported for CBD, CBG and CBC showed significant anti-inflammatory activity during DNBS-induced colitis in mice $[167,168]$. Cannabigerol reduced disease scores, attenuated alterations associated with oxidative stress and normalized cytokines expression [167]. Furthermore, in in vitro conditions, CBG also reduced nitric oxide $(\mathrm{NO})$ production in macrophages and reduced the formation of ROS in intestinal epithelial cells [167]. Similar effects were observed for CBC, which ameliorated DNBS-induced colonic inflammation and restored epithelial barrier function [168]. Additionally, CBC reduced LPS-induced activation of murine peritoneal macrophages in vitro, an effect likely contributing to its in vivo anti-inflammatory activity [168]. Lastly, a recent report has evaluated the anti-inflammatory effects of $\mathrm{CBDV}$, a compound under evaluation for the treatment of autism spectrum disorder and epilepsy/focal seizures $[94,169]$, thus supporting its therapeutic potential. Oral CBDV reduced colonic inflammation (structural damage, inflammatory infiltrate, altered permeability and cytokine production), in the DNBS-induced colitis model in mice [128]. CBDV also reduced cytokine expression in colonic biopsies from pediatric patients with $\mathrm{UC}$, which also supports the translational value of these observations [128]. 
Table 4. Anti-inflammatory activity of non-psychoactive phytocannabinoids in animal models of intestinal inflammation.

\begin{tabular}{|c|c|c|c|c|c|}
\hline Compound & Model & Species (Strain, Sex) & Type of Treatment & Main Effects on Inflammation-Related Parameters & Reference \\
\hline CBD & LPS & Mouse (Swiss OF1, males) & Preventive & $\begin{array}{l}\downarrow \text { Enteric glial activation } \\
\downarrow \text { Mast cell activation } \\
\downarrow \text { macrophages activation } \\
\downarrow \text { TNF- } \alpha \\
\downarrow \text { cleaved caspase-3 }(\downarrow \text { apoptosis) }\end{array}$ & [163] \\
\hline CBD & LPS & Rat (Sprague Dawley, N.S.) & Preventive & $\begin{array}{l}\downarrow \text { Histopathological alterations } \\
\downarrow \text { TNF- } \alpha \\
\downarrow \text { IL-6 } \\
\text { Restoration of smooth muscle myoelectrical activity }\end{array}$ & [132] \\
\hline CBD & LPS & Mouse (C57/BL, N.S.) & Preventive & $\begin{array}{l}\downarrow \text { IL-6 } \\
\text { Restoration of UGT }\end{array}$ & [132] \\
\hline CBD & TNBS & Mouse (CD1, males) & Preventive & $\begin{array}{l}\downarrow \text { Histopathological alterations (i.p. treatment) } \\
\text { No effects on histopathological alterations (oral treatment) } \\
\downarrow \text { Histopathological alterations (intrarectal treatment) }\end{array}$ & [164] \\
\hline CBD & TNBS & Rat (Wistar, males) & Preventive & $\begin{array}{l}\text { No effect on indices of inflammation } \\
\downarrow \text { MPO activity }\end{array}$ & [165] \\
\hline $\mathrm{CBD}+\mathrm{THC}$ & TNBS & Rat (Wistar, males) & Preventive & $\begin{array}{l}\downarrow \text { Indices of inflammation } \\
\downarrow \text { MPO activity }\end{array}$ & [165] \\
\hline CBD & DNBS & Mouse (ICR, males) & Preventive & $\begin{array}{l}\downarrow \text { Indices of inflammation } \\
\downarrow \text { Histopathological alterations } \\
\downarrow \text { iNOS expression } \\
\text { Normalization of IL-1 } \beta \text { and IL-10 levels }\end{array}$ & [166] \\
\hline CBD & DNBS & Mouse (ICR, males) & Curative & No effects on indices of inflammation & [131] \\
\hline $\begin{array}{l}\text { CBD (enriched } \\
\text { botanical extract) }\end{array}$ & DNBS & Mouse (ICR, males) & Curative & $\begin{array}{l}\downarrow \text { Indices of inflammation } \\
\downarrow \text { MPO activity }\end{array}$ & [131] \\
\hline $\begin{array}{l}\text { CBD (enriched } \\
\text { botanical extract) }\end{array}$ & Croton oil & Mouse (ICR, males) & Curative & $\downarrow$ Hypermotility (UGT) & [131] \\
\hline CBD & Croton oil & Mouse (ICR, males) & Curative & $\downarrow$ Hypermotility (UGT) & [131] \\
\hline CBD & Croton oil & Mouse (ICR, males) & Curative & Normalization of hypermotility (UGT) & [127] \\
\hline CBD & Croton oil & Mouse (ICR, males) & Curative & $\downarrow$ Hypermotility (UGT) & [130] \\
\hline
\end{tabular}


Table 4. Cont.

\begin{tabular}{|c|c|c|c|c|c|}
\hline Compound & Model & Species (Strain, Sex) & Type of Treatment & Main Effects on Inflammation-Related Parameters & Reference \\
\hline CBG & DNBS & Mouse (ICR, males) & Preventive & $\downarrow$ Indices of colitis & [167] \\
\hline CBG & DNBS & Mouse (ICR, males) & Curative & $\begin{array}{l}\downarrow \text { Indices of colitis } \\
\downarrow \text { Histopathological alterations } \\
\text { Restoration of epithelial barrier function } \\
\text { Normalization of IL-1 } \beta, \text { IL-10 and IFN- } \gamma \text { levels } \\
\text { Normalization of MPO activity } \\
\text { Normalization of SOD activity }\end{array}$ & [167] \\
\hline $\mathrm{CBC}$ & Croton oil & Mouse (ICR, males) & Curative & Normalization of UGT & [126] \\
\hline $\mathrm{CBC}$ & DNBS & Mouse (ICR, males) & Curative & $\begin{array}{l}\downarrow \text { Indices of colitis } \\
\downarrow \text { Histopathological alterations } \\
\text { Amelioration of epithelial barrier function } \\
\downarrow \text { MPO activity }\end{array}$ & [168] \\
\hline $\mathrm{CBC}$ & DNBS & Mouse (ICR, males) & Preventive & $\downarrow$ Indices of colitis & [168] \\
\hline CBDV & DNBS & Mouse (CD1, males) & Preventive & $\begin{array}{l}\downarrow \text { Indices of colitis } \\
\downarrow \text { MPO activity } \\
\text { Amelioration of epithelial barrier function } \\
\downarrow \text { Histopathological alterations }\end{array}$ & [128] \\
\hline CBDV & DNBS & Mouse (CD1, males) & Curative & $\begin{array}{l}\downarrow \text { Indices of colitis } \\
\downarrow \text { MPO activity } \\
\text { Amelioration of epithelial barrier function } \\
\downarrow \text { Histopathological alterations } \\
\text { Normalization of IL- } 1 \beta, \text { IL- } 6 \text {, and MCP- } 1 \alpha \text { expression } \\
\downarrow \text { Inflammation-associated dysbiosis }\end{array}$ & [128] \\
\hline CBDV & DSS & Mouse (CD1, males) & Curative & $\begin{array}{l}\downarrow \text { Indices of colitis } \\
\downarrow \text { MPO activity } \\
\downarrow \text { IL- } 1 \beta \text { levels }\end{array}$ & [128] \\
\hline
\end{tabular}

See abbreviations at the end of the chapter. 
The mechanisms by which cannabinoids exert their anti-inflammatory effects are still a matter of debate. Although cannabinoid receptors are expressed in relevant immune-related sites important in inflammatory responses, cannabinoids, particularly phytocannabinoids, also show activity on non-cannabinoid receptors known to participate in inflammatory mechanisms (see above). For instance, several non-psychoactive phytocannabinoids, such as CBN, CBD, CBC, CBDV, and CBG, act as agonists and desensitizers of different TRP channels $[56,170]$, known to participate in inflammatory responses and to be specifically regulated in IBD [171-173]. Additionally, indirect effects on cannabinoid receptors through the inhibition of endocannabinoid metabolism or uptake have also been described. For example, CBD, besides its effects on cannabinoid receptors, activate/desensitize a variety of TRP channels, including TRPV1, 2, 3 and ankyrin 1-type (TRPA1) [49,51]. Cannabidivarin shows very little affinity for cannabinoid receptors, but it is an inhibitor of endocannabinoid cellular reuptake [174], a weak inhibitor of MAGL (the main enzyme involved in the inactivation of the endocannabinoid 2-AG) and a potent activator of TRPA1 channels $[49,51,56]$. Therefore, part of the anti-inflammatory effects of the phytocannabinoids of interest here might be related to non-cannabinoid receptors-mediated effects or to reflect a modulation of the endocannabinoid tone/activity, thus avoiding some of the safety issues associated with the use of other cannabinoids.

Despite the relatively extensive pre-clinical evidence, only two studies have assessed, so far, the efficacy of non-psychoactive phytocannabinoids in a clinical setting, and these have addressed only the use of CBD (pure or a CBD rich botanical extract). The only study assessing the efficacy of CBD in $\mathrm{CD}$ was negative, with no improvement in disease activity as measured by a CD Activity Index (CDAI), as well as several laboratory parameters [175]. Interestingly, the treatment was safe, with no differences to placebo in adverse effects. As the authors discussed, the negative results might be due to the small number of cases included (19), the low dose tested (10 mg, orally) or the lack of the necessary synergism with other cannabinoids [175]. An additional proof-of-concept study addressed the effects of a CBD-rich botanical extract in UC [176]. The main result of this study was the lack of tolerability of the botanical extract, with $90 \%$ of patients reporting treatment-related adverse effects as compared with $48 \%$ receiving placebo. There was no difference in the primary endpoint of clinical remission between groups. However, there was a trend toward improved quality of life scores and improvement in patients' global impression of change based on the per-protocol analysis. The authors suggest that the CBD-rich botanical extract may have provided therapeutic benefit to those patients who tolerated it; and they encourage future studies, reviewing the formulation, titration, and dosing, to improve tolerability [176]. Overall, a recent meta-analysis that reviewed the evidence of cannabis and CBD on UC and CD was unable to make any firm conclusions on their safety or efficacy in IBD $[177,178]$. These reports concluded that further studies with a larger number of patients, different doses and routes of administration and a follow-up to assess the long-term safety outcomes are still necessary. Moreover, the potential use as nutraceuticals of CBD and other non-psychotropic phytocannabinoids should also be considered for clinical studies.

\subsection{Role in Gastrointestinal Cancer}

GI cancers, and particularly colorectal cancer (CRC), are among the most frequent in the general population $[179,180]$. Cannabinoids have been used historically to alleviate several cancer-related symptoms, such as pain, emesis, cachexia or dysgeusia, with the general objective of increasing patients' quality of life [181-183]. Significant changes in the ECS have been described in CRC. In particular, increased endocannabinoid levels, down-regulation of CB1 receptors and up-regulation of CB2 receptors have been observed in intestinal specimens of CRC patients $[184,185]$. These observations support the potential role of cannabinoids regulating cancer progression. The effects of cannabinoids on intestinal carcinogenesis have been evaluated in CRC epithelial cells, in experimental models of colon cancer and on gastric cancer cell lines [95,106,186,187]. Overall, cannabinoids might exert protective effects on carcinogenesis directly, through activation of cannabinoid receptors, or indirectly, through elevation of endocannabinoid levels via inhibition of metabolizing enzymes (particularly FAAH). In 
any case, activation of cannabinoid receptors is associated with anti-proliferative effects, the promotion of apoptosis, the inhibition of tumor cells migration and/or the inhibition of angiogenesis.

As it relates to non-psychoactive phytocannabinoids, the studies performed have centered on the potential anticancer use of CBD $[188,189]$. Interest in CBD is supported by evidence of its potential therapeutic value. First, its main mechanism of action (elevation of endocannabinoid levels by inhibition of enzymatic degradation) and pharmacological effects (antioxidant and anti-inflammatory) [189]. Secondly, CBD is known to have antitumor activity against Noxa activation, inhibition of mTOR/cyclin D1, and G-protein-coupled receptors/mitogen-activated protein kinase (GPR/MAPK) pathway in various cancers, such as pancreatic [190], glioblastoma [191], leukemia [192], and breast cancer [193]. Thirdly, GPR55 is implicated in the migratory behavior of HCT116 colon cancer cells and seems to play an important role in the prevention of metastasis [194]. Finally, the synthetic CBD analog, O-1602, has been shown to decrease viability and induce apoptosis in colon cancer cells and to reduce tumor area and tumor incidence in a colitis-associated colon cancer mouse model [195]. Altogether, this evidence suggests that CBD might have beneficial effects on GI cancers.

Multiple mechanisms are likely to be involved in CBD anti-proliferative effects in in vitro conditions, likely depending upon the CRC cell lines used. Early studies in SW40 colon cancer cells showed that CBD induces phosphatases and phosphatase-dependent apoptosis [196]. Subsequent studies in Caco-2 and HCT116 cells, showed that CBD protected DNA from oxidative damage, increased endocannabinoid levels and reduced cell proliferation in a CB1-, TRPV1- and PPAR $\gamma$-antagonists sensitive manner [197]. In HCT116, colo205 and DLD-1 tumor cells, apoptosis in a Noxa-and-ROS-dependent manner was observed upon exposure to CBD [198,199]. Interestingly, no toxic/anti-proliferative effects were observed in healthy colonic cells $[199,200]$, thus reinforcing the favorable safety profile of CBD. Consistent with these in vitro observations, anti-cancer effects of CBD have also been demonstrated in vivo in different murine models of CRC. In a model of azoxymethane-induced colon tumorigenesis in mice, a CBD-enriched botanical extract or pure CBD reduced preneoplastic lesion, polyps and tumor formation and counteracted some of the molecular changes associated with the process (up-regulation of phospho-Akt and down-regulation of caspase-3) $[197,200]$. Lastly, a recent study investigated the effect of CBD on the CT26 colon cancer line, in vivo, in an animal model showing encouraging effects on reducing colon cancer growth and decreasing tumor size, likely due to an increase of the antioxidant enzymes SOD and glutathione peroxidase (GPX) [201].

Similar effects to those observed for CBD in CRC cell lines have also been reported for gastric carcinoma cells. In human gastric cancer cells SGC-7901, CBD inhibited proliferation and colony formation through the induction of cell cycle arrest at the G0-G1 phase and apoptosis by increasing ROS [202]. Moreover, CBD promoted apoptosis in several gastric cancer cell lines (AGS, MKN45, SNU638, and NCI-N87) by X-linked inhibitor apoptosis (XIAP)/Smac-dependent mechanisms and mitochondrial dysfunction [203]. Interestingly, and as also reported for normal colonic cells, gastric normal epithelial HFE-145 cells were not affected [203].

Regarding other non-psychoactive phytocannabinoids, the information available is very limited. A report has assessed the anticancer effects of CBG on colon carcinogenesis, with similar general effects and mechanisms of action as those described for CBD. Cannabigerol inhibited the growth of CRC cells (Caco-2 and HTC 116) mainly via a pro-apoptotic mechanism, associated with ROS overproduction, and hindered the development and the growth of colon carcinogenesis in vivo (azoxymethane-induced colon tumorigenesis and HCT 116 CRC xenograft model in mice) [200]. An ethanol extract of Cannabis sativa enriched in CBGA showed low cytotoxic activity on colon cancer cells and a positive interaction with a THCA-enriched extract, which resulted in enhanced cytotoxic activity [204]. However, the interest of CBGA might be limited because of its low intrinsic activity and the fact that it did not show a positive interaction with other non-psychotropic phytocannabinoids (mainly CBD) on leukemic cells [192]. 
As it related to other GI cancers, the CB1 receptor is overexpressed in esophageal squamous carcinoma cell lines, and CB1 receptor activation appeared to promote cell proliferation and invasion [205]. Thus, a potential therapeutic utility in the treatment of esophageal cancer must be considered.

\subsection{Other Disorders and Diseases of the Gastrointestinal System}

\subsubsection{Nausea and Emesis}

Cannabis sativa plant has been used for several centuries for the attenuation of nausea and vomiting. Lately, the use of cannabinoids has been considered, particularly, for the control of symptoms of nausea and anticipatory nausea in chemotherapy patients, which are less well controlled by the current conventional therapies. The main drawback for their clinical use is their psychoactive effects. Therefore, non-psychoactive phytocannabinoids offer a safe alternative to other cannabinoids.

Preclinical research indicates that CBD may be clinically effective for treating both nausea and vomiting produced by chemotherapy or other therapeutic treatments. However, the clinical effectiveness of this compound in reducing nausea and vomiting has not been evaluated. Nevertheless, positive effects have been observed when combined with THC [206], and this combination (a mixture of THC and CBD in a ratio of approximately 1:1, together with small amounts of other cannabinoid derivatives; Sativex ${ }^{\circledR}$ ) is under further clinical investigation [207]. Cannabidiol, within a limited dose range, suppresses nausea and vomiting in different animal models by a non-cannabinoid receptor-dependent mechanism $[99,208,209]$. Indeed, the anti-nausea/anti-emetic effects of CBD may be mediated by indirect activation of somatodendritic $5-\mathrm{HT}_{1 \mathrm{~A}}$ receptors in the dorsal raphe nucleus; activation of these autoreceptors reduces the release of 5-HT in terminal forebrain regions [66,208]. However, some paradoxical effects of CBD on emesis have been described. Indeed, CBD seems to have a biphasic effect on emesis, with high and low doses potentiating and inhibiting, respectively, toxin-induced vomiting and anticipatory retching in S. murinus [208]. Of note, CBG, because of its antagonistic pharmacological activity at both $\mathrm{CB} 1$ and $5-\mathrm{HT}_{1 \mathrm{~A}}$ receptors, reverses the anti-emetic actions of low-dose CBD [210]. Moreover, the pro-emetic properties of CBD (at higher doses) and CBG may play a role in severe nausea and vomiting observed in patients with cannabinoid hyperemesis syndrome [211]. The cannabinoid hyperemesis syndrome (CHS) is a distinct syndrome, related to cyclic vomiting syndrome, characterized by recurrent vomiting associated with abdominal pain, hypothermia and compulsive hot bathing in the setting of chronic cannabinoid use [212,213]. Although the causes remain unknown, it has been associated with the potency of the THC consumed, the amount of use and the duration of use [213]. High levels of circulating THC might induce gastric stasis and delayed gastric emptying, contributing to the induction of nausea and vomiting, as suggested from animal studies assessing the effects of the synthetic cannabinoid WIN 55,212-2 on gastric motility [214,215]. Although interactions between the multiple phytocannabinoids present in Cannabis sativa have to be taken into consideration, the relevant role that THC seems to play suggests that its substitution (or at least reduction in concentration) by other phytocannabinoids might be beneficial in avoiding CHS. Therefore, the selective use of non-psychoactive phytocannabinoids might contribute to reducing the risk of $\mathrm{CHS}$ as a potential undesired side effect of chronic cannabinoid use.

\subsubsection{Gastric Secretion and Gastroprotection}

Overall, cannabinoids inhibit gastric secretion through CB1-dependent mechanisms that might implicate a modulation of vagal activity and a direct inhibitory effect of parietal cells $[95,101]$. CB1-dependent mechanisms also mediate gastroprotective effects of cannabinoids, as shown in different experimental models of gastric erosion and ulcer formation [95,101]. Gastroprotective effects of cannabinoids involve multiple mechanisms, implicating central and peripheral effects, as well as acid secretory-dependent and independent responses [101]. No specific studies have been performed assessing the effects of non-psychoactive phytocannabinoids. However, taking into consideration the 
effects described and the implication of local (gastric) mechanisms, the use of these compounds as nutraceuticals in this context warrants further investigations.

Based on the anti-inflammatory properties of CBD [156], its therapeutic potential in the management of chemo- and radiotherapy-induced oral mucositis (which might bear similarities with gastric erosions and ulcers) has been assessed [216]. In a preclinical study in rats, CBD exerted an anti-inflammatory effect in the early phase of oral wound healing process although it was not sufficient to promote the clinical improvement of oral traumatic ulcerative lesions [217]. In any case, the clinical data available is not conclusive, and additional studies are required. Again, because of the desired local action, the administration of CBD, or other non-psychoactive phytocannabinoids, as nutraceuticals should be considered.

\subsubsection{Gastroesophageal Reflux Disease}

The lower esophageal sphincter (LES), a specialized region of the esophageal circular smooth muscle, allows the passage of a swallowed bolus to the stomach and prevents the reflux of gastric contents into the esophagus. The cannabinoid system has been implicated in the mechanisms regulating LES relaxation [218]. In dogs and ferrets, cannabinoids inhibited transient LES relaxations through a CB1-dependent mechanism. These observations are of interest because transient LES relaxations are the predominant mechanism of gastroesophageal reflux disease [218]. In line with these preclinical observations, positive effects of THC have been observed in humans, although with issues related to the safety profile (central psychotropic activity) [219]. Besides the inhibition of transient LES relaxations, multiple pharmacological actions might contribute to the beneficial effects of cannabinoids in the treatment of gastroesophageal reflux disease: Inhibition of gastric acid secretion, reduction of microvascular leakage and bronchoconstriction associated with reflux and reduction of pain associated with esophageal hypersensitivity [218].

Studies performed so far have concentrated on the use of THC or different synthetic cannabinoids, without data available as it relates to non-psychoactive phytocannabinoids. Nevertheless, the current knowledge indicates that the use of non-psychoactive phytocannabinoids for the treatment of gastroesophageal reflux disease is worthy of exploring as an adjunct therapy with acid inhibition.

In summary, compelling evidence, both preclinical and clinical, supports the view that non-psychoactive phytocannabinoids have therapeutic potential for the treatment of several GI diseases and as promoters of GI health. Nevertheless, the clinical evidence is still limited, and additional studies are necessary, addressing both efficacy and safety. In particular, CBD has raised significant interest, mainly following its reschedule by the USA Drug Enforcement Administration (DEA) to the least restrictive Schedule V category, as of September 2018 (compared to cannabis, included in Schedule I category) [116]. In many instances, nutraceuticals are regarded as disease-preventive treatments. However, no clinical studies have been performed addressing this potential use. Nevertheless, preclinical data in animal models of intestinal inflammation suggest that phytocannabinoids might act both preventing the development of inflammation, as well as ameliorating an already established state of inflammation. This suggests, at least, a potential in the maintenance of the remission state and the prevention of disease flares in IBD patients.

\section{Conclusions}

Phytocannabinoids exert potent actions throughout the body. Data reported mainly from preclinical research, but also from the available clinical evidence, have demonstrated their high therapeutic potential to treat the diseased GI tract, from functional to organic pathologies. This not only applies to the well-known psychoactive compound, THC, but also to non-psychoactive molecules like CBD and others which have been more scarcely studied so far.

Interestingly, the non-psychoactive phytocannabinoids may be considered as nutraceuticals, and it is envisaged that they will soon find their place, not only in therapy, but in the food industry, leading to new formulations for a healthy life in general, and for a healthy GI tract function, in particular. 
The eventual introduction and wide use of hemp-derived non-psychoactive phytocannabinoids as food ingredients will require clearer (and more flexible) regulations, based on clear, evidence-based, scientifically demonstrated, knowledge of their effects and mechanisms of action, which are urgently needed.

Author Contributions: Conceptualization, R.A.; review of literature, V.M., A.I.D.-H., F.B., R.C., M.D.d.C.; writing-original draft preparation, V.M., A.I.D.-H., F.B., R.C., M.D.d.C.; writing-review and editing, V.M., A.I.D.-H., F.B., R.C., M.D.d.C., R.A.; supervision, R.C., R.A. All authors have read and agreed to the published version of the manuscript.

Funding: This research was funded by CSIC, 201970E117.

Acknowledgments: The authors are grateful to Mary Ann Liebert, Inc., publishers for the permission of use of Figure 1.

Conflicts of Interest: The authors declare no conflict of interest.

\section{Abbreviations}

2-AG

2-AGE

$5-\mathrm{HT}_{1 \mathrm{~A}}$

$5-\mathrm{HT}_{2 \mathrm{~A}}$

$5 \mathrm{HT}_{3 \mathrm{~A}}$

A

ABHD6/12

AEA

AIDS

CB1

CB2

$\mathrm{CBC}$

CBCA

CBD

CBD-BDS

CBDA

CBDV

CBG

CBGA

CBN

CBNA

CBNDA

CD

CDAI

CHS

CNS

COX

CRC

DAG

DAGL

DEA

DNBS

DSS

ECS

EFSA

EMT

ENS

EU 2-arachidonoylglycerol

Noladin ether, 2-arachidonoylglycerylether

5-hydroxytryptamine $1 \mathrm{~A}$ receptor

5-hydroxytryptamine $2 \mathrm{~A}$ receptor

5-hydroxytryptamine $3 \mathrm{~A}$ receptor

Adenosine receptor

$\alpha / \beta$-hydrolase domain $6 / 12$

Anandamide, arachidonylethanolamide

Acquired immunodeficiency syndrome

Cannabinoid receptor 1

Cannabinoid receptor 2

Cannabichromene

Cannabichromenic acid

Cannabidiol

Cannabidiol-botanical drug substance

Cannabidiolic acid

Cannabidivarin

Cannabigerol

Cannabigerolic acid

Cannabinol

Cannabinolic acid

Cannabinodiolic acid

Crohn's disease

Crohn's disease activity index

Cannabinoid hyperemesis syndrome

Central nervous system

Cyclooxygenase

Colorectal cancer

Diacylglycerol

Diacylglycerol lipase

Drug Enforcement Administration

Dinitrobenzene sulphonic acid

Dextrane sulfate sodium

Endocannabinoid system, endogenous cannabinoid system

European Food Safety Authority's

Endocannabinoid membrane transporter

Enteric nervous system

European Union 
FAAH

FABP

FDA

FUFOSE

GABA

$\mathrm{GABA}_{\mathrm{A}}$

GI

GLP-1

GlyR

GPR

GPX

IBD

IBS

IBS-C

IBS-D

IBS-M

IFN

IL

i.p.

iNOS

LES

LOX

LPI

LPS

MAGL

MAPK

MCP- $1 \alpha$

$\mathrm{MPO}$

NAAA

NADA

NAPE

NAPE-PLD

$\mathrm{NO}$

O-AEA

OEA

PEA

PNS

PPAR $\alpha$

PPAR $\gamma$

ROS

SOD

THC

THCA

TNBS

TNF

TRP

TRPA1

TRPM8

TRPV1

TRPV2

TRPV3

TRPV4
Fatty acid amide hydrolase

Fatty acid binding protein

Food and Drug Administration

Functional Food Science in Europe

$\gamma$-aminobutyric acid

$\gamma$-aminobutyric acid type A receptor

Gastrointestinal

Glucagon like peptide 1

Glycine receptor

$\mathrm{G}$ protein-coupled receptor

Glutathione peroxidase

Inflammatory bowel disease

Irritable bowel syndrome

Irritable bowel syndrome with constipation

Irritable bowel syndrome with diarrhea

Irritable bowel syndrome with mixed bowel habits

Interferon

Interleukine

Intraperitoneal

Inducible nitric oxide synthase

Lower esophageal sphincter

Lipooxygenase

Lysophosphatidylinositol

Lipopolysaccharide

Monoacylglycerol lipase

Mitogen-activated protein kinase

Monocyte chemoattractant protein- $1 \alpha$

Myeloperoxidase

$\mathrm{N}$-acylethanolamine acid amide hydrolase, $\mathrm{N}$-acylethanolamine

hydrolyzing acid amidase

$\mathrm{N}$-arachidonoyldopamine

$\mathrm{N}$-acyl-phosphatidylethanolamine

N-acyl-phosphatidylethanolamine-specific phospholipase D

Nitric oxide

Virodhamine, O-arachidonoylethanolamine

Oleylethanolamide

Palmithoylethanolamide

Peripheral nervous system

Peroxisome proliferator-activated receptor type- $\alpha$

Peroxisome proliferator-activated receptor type- $\gamma$

Reactive oxygen species

Superoxide dismutase

$\Delta^{9}$-tetrahydrocannabinol

Tetrahydrocannabinolic acid

Trinitrobenzene sulfonic acid

Tumor necrosis factor

Transient receptor potential

Transient receptor potential cation channel subfamily ankyrin 1-type

Transient receptor potential cation channel subfamily M member 8

Transient receptor potential vanilloid type-1 channel

Transient receptor potential cation channel subfamily $\mathrm{V}$ member 2

Transient receptor potential cation channel subfamily $\mathrm{V}$ member 3

Transient receptor potential cation channel subfamily $\mathrm{V}$ member 4 
UC

UGT

USDA

XIAP

$\Delta^{9}$-THC-BDS
Ulcerative colitis

Upper gastrointestinal transit

United States Department of Agriculture

$\mathrm{X}$-linked inhibitor apoptosis

$\Delta^{9}$-tetrahydrocannabinol-botanical drug substance

\section{References}

1. Gao, X.; Liu, J.; Li, L.; Liu, W.; Sun, M. A brief review of nutraceutical ingredients in gastrointestinal disorders: Evidence and suggestions. Int. J. Mol. Sci. 2020, 21, 1822. [CrossRef] [PubMed]

2. Larussa, T.; Imeneo, M.; Luzza, F. Potential role of nutraceutical compounds in inflammatory bowel disease. World J. Gastroenterol. 2017, 23, 2483-2492. [CrossRef] [PubMed]

3. Larussa, T.; Rossi, M.; Suraci, E.; Marasco, R.; Imeneo, M.; Abenavoli, L.; Luzza, F. Use of complementary and alternative medicine by patients with irritable bowel syndrome according to the roma IV criteria: A single-center italian survey. Medicina 2019, 55, 46. [CrossRef] [PubMed]

4. McPartland, J.M. Cannabis Systematics at the Levels of Family, Genus, and Species. Cannabis Cannabinoid Res. 2018, 3, 203-212. [CrossRef]

5. Morales, P.; Hurst, D.P.; Reggio, P.H. Molecular Targets of the Phytocannabinoids: A Complex Picture. In Phytocannabinoids. Unraveling the Complex Chemistry and Pharmacology of Cannabis sativa; Kinghorn, A.D., Falk, H., Gibbons, S., Kobayashi, J., Eds.; Springer International Publishing: Cham, Switzerland, 2017; Volume 103, pp. 103-131. ISBN 9783319455396.

6. Gertsch, J. Cannabimimetic phytochemicals in the diet-An evolutionary link to food selection and metabolic stress adaptation? Br. J. Pharmacol. 2017, 174, 1464-1483. [CrossRef]

7. Johnson, R. Defining Hemp: A Fact Sheet; Congressional Research Service: Washington, DC, USA, 2019.

8. Leonard, W.; Zhang, P.; Ying, D.; Fang, Z. Hempseed in food industry: Nutritional value, health benefits, and industrial applications. Compr. Rev. Food Sci. Food Saf. 2019, 1-27. [CrossRef]

9. Salentijn, E.M.J.; Zhang, Q.; Amaducci, S.; Yang, M.; Trindade, L.M. New developments in fiber hemp (Cannabis sativa L.) breeding. Ind. Crops Prod. 2015, 68, 32-41. [CrossRef]

10. Garcia, A.G.M. Hemp: A Composition Review Plus; Food Science and Nutrition Department, California Polytechnic State University: San Luis Obispo, CA, USA, 2017; Volume 102.

11. Audu, B.S.; Ofojekwu, P.C.; Ujah, A.; Ajima, M.N.O. Phytochemical, proximate composition, amino acid profile and characterisation of Marijuana (Cannabis sativa L.). Phytopharmacology 2014, 3, 35-43.

12. Andre, C.M.; Hausman, J.F.; Guerriero, G. Cannabis sativa: The plant of the thousand and one molecules. Front. Plant Sci. 2016, 7, 1-17. [CrossRef]

13. Pacifico, D.; Miselli, F.; Carboni, A.; Moschella, A.; Mandolino, G. Time course of cannabinoid accumulation and chemotype development during the growth of Cannabis sativa L. Euphytica 2008, 160, 231-240. [CrossRef]

14. Callaway, J.C. Hempseed as a nutritional resource: An overview. Euphytica 2004, 140, 65-72. [CrossRef]

15. Vonapartis, E.; Aubin, M.P.; Seguin, P.; Mustafa, A.F.; Charron, J.B. Seed composition of ten industrial hemp cultivars approved for production in Canada. J. Food Compos. Anal. 2015, 39, 8-12. [CrossRef]

16. Wang, M.; Wang, Y.H.; Avula, B.; Radwan, M.M.; Wanas, A.S.; Van Antwerp, J.; Parcher, J.F.; Elsohly, M.A.; Khan, I.A. Decarboxylation Study of Acidic Cannabinoids: A Novel Approach Using Ultra-High-Performance Supercritical Fluid Chromatography/Photodiode Array-Mass Spectrometry. Cannabis Cannabinoid Res. 2016, 1, 262-271. [CrossRef] [PubMed]

17. Cardenia, V.; Gallina Toschi, T.; Scappini, S.; Rubino, R.C.; Rodriguez-Estrada, M.T. Development and validation of a Fast gas chromatography/mass spectrometry method for the determination of cannabinoids in Cannabis sativa L. J. Food Drug Anal. 2018, 26, 1283-1292. [CrossRef] [PubMed]

18. Kalra, E.K. Nutraceutical-Definition and introduction. AAPS J. 2003, 5, 1-2. [CrossRef]

19. Martirosyan, D.M.; Singh, J. A new definition of functional food by FFC: What makes a new definition unique? Funct. Foods Heal. Dis. 2015, 5, 209-223. [CrossRef]

20. The European Commission. Functional Foods; Publications Office of the European Union: Luxembourg, 2010.

21. King, J.W. The relationship between cannabis/hemp use in foods and processing methodology. Curr. Opin. Food Sci. 2019, 28, 32-40. [CrossRef] 
22. USDA (United States Department of Agriculture USA) FoodData Central. Available online: https://fdc.nal. usda.gov/fdc-app.html\#/?query=hemp (accessed on 25 March 2020).

23. European Comission Novel Food Catalogue. Available online: https://ec.europa.eu/food/safety/novel_food/ catalogue_en (accessed on 27 January 2020).

24. EFSA Panel on Dietetic Products; Nutrition and Allergies (NDA); Turck, D.; Bresson, J.L.; Burlingame, B.; Dean, T.; Fairweather-Tait, S.; Heinonen, M.; Hirsch-Ernst, K.I.; Mangelsdorf, I.; et al. Guidance on the preparation and presentation of an application for authorisation of a novel food in the context of Regulation (EU) 2015/2283. EFSA J. 2016, 14, e04594.

25. Másílko, M.; Sadílek, T.; Martin, T.; Jurado, E. Cannabidiol (CBD) and Hemp: Novel Food Status in the EU; Int. Cannabis Cannabinoids Inst: Prague, Czech Republic, 2019.

26. Di Marzo, V. New approaches and challenges to targeting the endocannabinoid system. Nat. Rev. Drug Discov. 2018, 17, 623-639. [CrossRef]

27. Chye, Y.; Christensen, E.; Solowij, N.; Yücel, M. The endocannabinoid system and cannabidiol's promise for the treatment of substance use disorder. Front. Psychiatry 2019, 10, 1-12. [CrossRef]

28. Devane, W.A.; Dysarz, F.A.; Johnson, M.R.; Melvin, L.S.; Howlett, A.C. Determination and characterization of a cannabinoid receptor in rat brain. Mol. Pharmacol. 1988, 34, 605-613. [PubMed]

29. Salio, C.; Doly, S.; Fischer, J.; Franzoni, M.F.; Conrath, M. Neuronal and astrocytic localization of the cannabinoid receptor-1 in the dorsal horn of the rat spinal cord. Neurosci. Lett. 2002, 329, 13-16. [CrossRef]

30. Stella, N. Cannabinoid and cannabinoid-like receptors in microglia, astrocytes, and astrocytomas. Glia 2010, 58, 1017-1030. [CrossRef] [PubMed]

31. Mackie, K. Distribution of Cannabinoid Receptors in the Central and Peripheral Nervous System. In Cannabinoids; Springer-Verlag: Berlin/Heidelberg, 2005; Volume 20, pp. 299-325. ISBN 354022565X.

32. Pesce, M.; D’Alessandro, A.; Borrelli, O.; Gigli, S.; Seguella, L.; Cuomo, R.; Esposito, G.; Sarnelli, G. Endocannabinoid-related compounds in gastrointestinal diseases. J. Cell. Mol. Med. 2018, 22, 706-715. [CrossRef] [PubMed]

33. O'Sullivan, S.E. Endocannabinoids and the Cardiovascular System in Health and Disease. In Endocannabinoids; Springer: Cham, Switzerland, 2015; pp. 393-422. ISBN 9783319208251.

34. Kaschina, E. Cannabinoid CB1/CB2 Receptors in the Heart: Expression, Regulation, and Function. In Cannabinoids in Health and Disease; InTech: London, UK, 2016; Volume i, p. 13.

35. Dhopeshwarkar, A.; Mackie, K. CB 2 Cannabinoid Receptors as a Therapeutic Target-What Does the Future Hold? Mol. Pharmacol. 2014, 86, 430-437. [CrossRef] [PubMed]

36. Matsuda, L.A.; Lolait, S.J.; Brownstein, M.J.; Young, A.C.; Bonner, T.I. Structure of a cannabinoid receptor and functional expression of the cloned cDNA. Nature 1990, 346, 561-564. [CrossRef] [PubMed]

37. Zou, S.; Kumar, U. Cannabinoid receptors and the endocannabinoid system: Signaling and function in the central nervous system. Int. J. Mol. Sci. 2018, 19, 833.

38. Iannotti, F.A.; Di Marzo, V.; Petrosino, S. Endocannabinoids and endocannabinoid-related mediators: Targets, metabolism and role in neurological disorders. Prog. Lipid Res. 2016, 62, 107-128. [CrossRef]

39. Frassinetti, S.; Moccia, E.; Caltavuturo, L.; Gabriele, M.; Longo, V.; Bellani, L.; Giorgi, G.; Giorgetti, L. Nutraceutical potential of hemp (Cannabis sativa L.) seeds and sprouts. Food Chem. 2018, 262, 56-66. [CrossRef]

40. Brighenti, V.; Pellati, F.; Steinbach, M.; Maran, D.; Benvenuti, S. Development of a new extraction technique and HPLC method for the analysis of non-psychoactive cannabinoids in fibre-type Cannabis sativa L. (hemp). J. Pharm. Biomed. Anal. 2017, 143, 228-236. [CrossRef]

41. Pellati, F.; Borgonetti, V.; Brighenti, V.; Biagi, M.; Benvenuti, S.; Corsi, L. Cannabis sativa L. and Nonpsychoactive Cannabinoids: Their Chemistry and Role against Oxidative Stress, Inflammation, and Cancer. Biomed Res. Int. 2018, 2018. [CrossRef] [PubMed]

42. Bayewitch, M.; Rhee, M.H.; Avidor-Reiss, T.; Breuer, A.; Mechoulam, R.; Vogel, Z. (-)- $\Delta$ 9-Tetrahydrocannabinol antagonizes the peripheral cannabinoid receptor-mediated inhibition of adenylyl cyclase. J. Biol. Chem. 1996, 271, 9902-9905. [CrossRef] [PubMed]

43. Lauckner, J.E.; Jensen, J.B.; Chen, H.Y.; Lu, H.C.; Hille, B.; Mackie, K. GPR55 is a cannabinoid receptor that increases intracellular calcium and inhibits M current. Proc. Natl. Acad. Sci. USA 2008, 105, 2699-2704. [CrossRef] [PubMed] 
44. McHugh, D.; Page, J.; Dunn, E.; Bradshaw, H.B. $\Delta$ 9-tetrahydrocannabinol and N-arachidonyl glycine are full agonists at GPR18 receptors and induce migration in human endometrial HEC-1B cells. Br. J. Pharmacol. 2012, 165, 2414-2424. [CrossRef] [PubMed]

45. Console-Bram, L.; Brailoiu, E.; Brailoiu, G.C.; Sharir, H.; Abood, M.E. Activation of GPR18 by cannabinoid compounds: A tale of biased agonism. Br. J. Pharmacol. 2014, 171, 3908-3917. [CrossRef] [PubMed]

46. Yang, K.H.S.; Isaev, D.; Morales, M.; Petroianu, G.; Galadari, S.; Oz, M. The effect of $\delta 9$-tetrahydrocannabinol on 5-HT3 receptors depends on the current density. Neuroscience 2010, 171, 40-49. [CrossRef] [PubMed]

47. O'Sullivan, S.E.; Tarling, E.J.; Bennett, A.J.; Kendall, D.A.; Randall, M.D. Novel time-dependent vascular actions of $\Delta$ 9- tetrahydrocannabinol mediated by peroxisome proliferator-activated receptor gamma. Biochem. Biophys. Res. Commun. 2005, 337, 824-831. [CrossRef]

48. O'Sullivan, S.E.; Kendall, D.A.; Randall, M.D. Further characterization of the time-dependent vascular effects of $\Delta$-tetrahydrocannabinol. J. Pharmacol. Exp. Ther. 2006, 317, 428-438. [CrossRef]

49. De Petrocellis, L.; Vellani, V.; Schiano-Moriello, A.; Marini, P.; Magherini, P.C.; Orlando, P.; Di Marzo, V. Plant-derived cannabinoids modulate the activity of transient receptor potential channels of ankyrin type-1 and melastatin type-8. J. Pharmacol. Exp. Ther. 2008, 325, 1007-1015. [CrossRef]

50. Qin, N.; Neeper, M.P.; Liu, Y.; Hutchinson, T.L.; Lubin, M.L.; Flores, C.M. TRPV2 is activated by cannabidiol and mediates CGRP release in cultured rat dorsal root ganglion neurons. J. Neurosci. 2008, 28, 6231-6238. [CrossRef]

51. De Petrocellis, L.; Orlando, P.; Moriello, A.S.; Aviello, G.; Stott, C.; Izzo, A.A.; di Marzo, V. Cannabinoid actions at TRPV channels: Effects on TRPV3 and TRPV4 and their potential relevance to gastrointestinal inflammation. Acta Physiol. 2012, 204, 255-266. [CrossRef] [PubMed]

52. Vaysse, P.J.; Gardner, E.L.; Zukin, R.S. Modulation of Rat Brain Opioid Receptors by Cannabinoids1. J. Pharmacol. Exp. Ther. 1987, 241, 534-539. [PubMed]

53. Kathmann, M.; Flau, K.; Redmer, A.; Tränkle, C.; Schlicker, E. Cannabidiol is an allosteric modulator at mu- and delta-opioid receptors. Naunyn. Schmiedebergs. Arch. Pharmacol. 2006, 372, 354-361. [CrossRef] [PubMed]

54. Xiong, W.; Cheng, K.; Cui, T.; Godlewski, G.; Rice, K.C.; Xu, Y.; Zhang, L. Cannabinoid potentiation of glycine receptors contributes to cannabis-induced analgesia. Nat. Chem. Biol. 2011, 7, 296-303. [CrossRef] [PubMed]

55. Bisogno, T.; Hanuš, L.; De Petrocellis, L.; Tchilibon, S.; Ponde, D.E.; Brandi, I.; Moriello, A.S.; Davis, J.B.; Mechoulam, R.; Di Marzo, V. Molecular targets for cannabidiol and its synthetic analogues: Effect on vanilloid VR1 receptors and on the cellular uptake and enzymatic hydrolysis of anandamide. Br. J. Pharmacol. 2001, 134, 845-852. [CrossRef] [PubMed]

56. De Petrocellis, L.; Ligresti, A.; Moriello, A.S.; Allarà, M.; Bisogno, T.; Petrosino, S.; Stott, C.G.; Di Marzo, V. Effects of cannabinoids and cannabinoid-enriched Cannabis extracts on TRP channels and endocannabinoid metabolic enzymes. Br. J. Pharmacol. 2011, 163, 1479-1494. [CrossRef] [PubMed]

57. Elmes, M.W.; Kaczocha, M.; Berger, W.T.; Leung, K.N.; Ralph, B.P.; Wang, L.; Sweeney, J.M.; Miyauchi, J.T.; Tsirka, S.E.; Ojima, I.; et al. Fatty acid-binding proteins (FABPs) are intracellular carriers for $\Delta$ 9-tetrahydrocannabinol (THC) and cannabidiol (CBD). J. Biol. Chem. 2015, 290, 8711-8721. [CrossRef] [PubMed]

58. Carrier, E.J.; Auchampach, J.A.; Hillard, C.J. Inhibition of an equilibrative nucleoside transporter by cannabidiol: A mechanism of cannabinoid immunosuppression. Proc. Natl. Acad. Sci. USA 2006, 103, 7895-7900. [CrossRef]

59. Pertwee, R.G. Handbook of Cannabis; Pertwee, R.G., Ed.; Oxford University Press: Oxford, UK, 2014.

60. Laprairie, R.B.; Bagher, A.M.; Kelly, M.E.M.; Denovan-Wright, E.M. Cannabidiol is a negative allosteric modulator of the cannabinoid CB1 receptor. Br. J. Pharmacol. 2015, 172, 4790-4805. [CrossRef]

61. Martínez-Pinilla, E.; Varani, K.; Reyes-Resina, I.; Angelats, E.; Vincenzi, F.; Ferreiro-Vera, C.; Oyarzabal, J.; Canela, E.I.; Lanciego, J.L.; Nadal, X.; et al. Binding and signaling studies disclose a potential allosteric site for cannabidiol in cannabinoid CB2 receptors. Front. Pharmacol. 2017, 8, 1-10. [CrossRef]

62. Ryberg, E.; Larsson, N.; Sjögren, S.; Hjorth, S.; Hermansson, N.O.; Leonova, J.; Elebring, T.; Nilsson, K.; Drmota, T.; Greasley, P.J. The orphan receptor GPR55 is a novel cannabinoid receptor. Br. J. Pharmacol. 2007, 152, 1092-1101. [CrossRef] [PubMed]

63. Laun, A.S.; Song, Z.H. GPR3 and GPR6, novel molecular targets for cannabidiol. Biochem. Biophys. Res. Commun. 2017, 490, 17-21. [CrossRef] [PubMed] 
64. Brown, K.J.; Laun, A.S.; Song, Z.H. Cannabidiol, a novel inverse agonist for GPR12. Biochem. Biophys. Res. Commun. 2017, 493, 451-454. [CrossRef] [PubMed]

65. Gonca, E.; Darici, F. The Effect of Cannabidiol on ischemia/reperfusion-induced ventricular arrhythmias: The role of adenosine a1 receptors. J. Cardiovasc. Pharmacol. Ther. 2015, 20, 76-83. [CrossRef]

66. Russo, E.B.; Burnett, A.; Hall, B.; Parker, K.K. Agonistic properties of cannabidiol at 5-HT1a receptors. Neurochem. Res. 2005, 30, 1037-1043. [CrossRef]

67. Yang, K.H.; Galadari, S.; Isaev, D.; Petroianu, G.; Shippenberg, T.S.; Oz, M. The nonpsychoactive cannabinoid cannabidiol inhibits 5- hydroxytryptamine3A receptor-mediated currents in xenopus laevis oocytes. J. Pharmacol. Exp. Ther. 2010, 333, 547-554. [CrossRef] [PubMed]

68. O'Sullivan, S.E.; Sun, Y.; Bennett, A.J.; Randall, M.D.; Kendall, D.A. Time-dependent vascular actions of cannabidiol in the rat aorta. Eur. J. Pharmacol. 2009, 612, 61-68. [CrossRef]

69. Bakas, T.; van Nieuwenhuijzen, P.S.; Devenish, S.O.; McGregor, I.S.; Arnold, J.C.; Chebib, M. The direct actions of cannabidiol and 2-arachidonoyl glycerol at GABAA receptors. Pharmacol. Res. 2017, 119, 358-370. [CrossRef]

70. Ahrens, J.; Demir, R.; Leuwer, M.; De La Roche, J.; Krampfl, K.; Foadi, N.; Karst, M.; Haeseler, G. The nonpsychotropic cannabinoid cannabidiol modulates and directly activates alpha-1 and alpha-1-beta glycine receptor function. Pharmacology 2009, 83, 217-222. [CrossRef]

71. Xiong, W.; Cui, T.; Cheng, K.; Yang, F.; Chen, S.R.; Willenbring, D.; Guan, Y.; Pan, H.L.; Ren, K.; Xu, Y.; et al. Cannabinoids suppress inflammatory and neuropathic pain by targeting $\alpha 3$ glycine receptors. J. Exp. Med. 2012, 209, 1121-1134. [CrossRef]

72. Rosenthaler, S.; Pöhn, B.; Kolmanz, C.; Nguyen Huu, C.; Krewenka, C.; Huber, A.; Kranner, B.; Rausch, W.D.; Moldzio, R. Differences in receptor binding affinity of several phytocannabinoids do not explain their effects on neural cell cultures. Neurotoxicol. Teratol. 2014, 46, 49-56. [CrossRef] [PubMed]

73. Navarro, G.; Varani, K.; Reyes-Resina, I.; de Medina, V.S.; Rivas-Santisteban, R.; Callado, C.S.C.; Vincenzi, F.; Casano, S.; Ferreiro-Vera, C.; Canela, E.I.; et al. Cannabigerol action at cannabinoid CB1 and CB2 receptors and at CB1-CB2 heteroreceptor complexes. Front. Pharmacol. 2018, 9, 1-14. [CrossRef] [PubMed]

74. Anavi-Goffer, S.; Baillie, G.; Irving, A.J.; Gertsch, J.; Greig, I.R.; Pertwee, R.G.; Ross, R.A. Modulation of L- $\alpha$-lysophosphatidylinositol/GPR55 mitogen-activated protein kinase (MAPK) signaling by cannabinoids. J. Biol. Chem. 2012, 287, 91-104. [CrossRef] [PubMed]

75. Cascio, M.G.; Gauson, L.A.; Stevenson, L.A.; Ross, R.A.; Pertwee, R.G. Evidence that the plant cannabinoid cannabigerol is a highly potent $\alpha$ 2-adrenoceptor agonist and moderately potent 5HT 1A receptor antagonist. Br. J. Pharmacol. 2010, 159, 129-141. [CrossRef] [PubMed]

76. Hill, A.J.; Jones, N.A.; Smith, I.; Hill, C.L.; Williams, C.M.; Stephens, G.J.; Whalley, B.J. Voltage-gated sodium $(\mathrm{NaV})$ channel blockade by plant cannabinoids does not confer anticonvulsant effects per se. Neurosci. Lett. 2014, 566, 269-274. [CrossRef] [PubMed]

77. Udoh, M.; Santiago, M.; Devenish, S.; McGregor, I.S.; Connor, M. Cannabichromene is a cannabinoid CB2 receptor agonist. Br. J. Pharmacol. 2019, 176, 4537-4547. [CrossRef] [PubMed]

78. Bolognini, D.; Rock, E.M.; Cluny, N.L.; Cascio, M.G.; Limebeer, C.L.; Duncan, M.; Stott, C.G.; Javid, F.A.; Parker, L.A.; Pertwee, R.G. Cannabidiolic acid prevents vomiting in Suncus murinus and nausea-induced behaviour in rats by enhancing 5-HT1A receptor activation. Br. J. Pharmacol. 2013, 168, 1456-1470. [CrossRef]

79. Maroon, J.; Bost, J. Review of the neurological benefits of phytocannabinoids. Surg. Neurol. Int. 2018,9 , 91. [CrossRef]

80. Boggs, D.L.; Nguyen, J.D.; Morgenson, D.; Taffe, M.A.; Ranganathan, M. Clinical and Preclinical Evidence for Functional Interactions of Cannabidiol and $\Delta^{9}$-Tetrahydrocannabinol. Neuropsychopharmacology 2018, 43, 142-154. [CrossRef]

81. Hudson, R.; Renard, J.; Norris, C.; Rushlow, W.J.; Laviolette, S.R. Cannabidiol Counteracts the Psychotropic Side-Effects of $\Delta-9$-Tetrahydrocannabinol in the Ventral Hippocampus through Bidirectional Control of ERK1-2 Phosphorylation. J. Neurosci. 2019, 39, 8762-8777. [CrossRef]

82. Pisanti, S.; Malfitano, A.M.; Ciaglia, E.; Lamberti, A.; Ranieri, R.; Cuomo, G.; Abate, M.; Faggiana, G.; Proto, M.C.; Fiore, D.; et al. Cannabidiol: State of the art and new challenges for therapeutic applications. Pharmacol. Ther. 2017, 175, 133-150. [CrossRef] [PubMed] 
83. Noreen, N.; Muhammad, F.; Akhtar, B.; Azam, F.; Anwar, M.I. Is cannabidiol a promising substance for new drug development? A review of its potential therapeutic applications. Crit. Rev. Eukaryot. Gene Expr. 2018, 28, 73-86. [CrossRef] [PubMed]

84. Chagas, M.H.N.; Eckeli, A.L.; Zuardi, A.W.; Pena-Pereira, M.A.; Sobreira-Neto, M.A.; Sobreira, E.T.; Camilo, M.R.; Bergamaschi, M.M.; Schenck, C.H.; Hallak, J.E.C.; et al. Cannabidiol can improve complex sleep-related behaviours associated with rapid eye movement sleep behaviour disorder in Parkinson's disease patients: A case series. J. Clin. Pharm. Ther. 2014, 39, 564-566. [CrossRef] [PubMed]

85. Shannon, S.; Lewis, N.; Lee, H.; Hughes, S. Cannabidiol in Anxiety and Sleep: A Large Case Series. Perm. J. 2019, 23, 18-041. [CrossRef] [PubMed]

86. Pinto, J.V.; Saraf, G.; Frysch, C.; Vigo, D.; Keramatian, K.; Chakrabarty, T.; Lam, R.W.; Kauer-Sant'Anna, M.; Yatham, L.N. Cannabidiol as a Treatment for Mood Disorders: A Systematic Review. Can. J. Psychiatry 2020, 65, 213-227. [CrossRef] [PubMed]

87. Peres, F.F.; Lima, A.C.; Hallak, J.E.C.; Crippa, J.A.; Silva, R.H.; Abílio, V.C. Cannabidiol as a promising strategy to treat and prevent movement disorders? Front. Pharmacol. 2018, 9, 1-12. [CrossRef]

88. Aso, E.; Fernández-Dueñas, V.; López-Cano, M.; Taura, J.; Watanabe, M.; Ferrer, I.; Luján, R.; Ciruela, F. Adenosine A2A-Cannabinoid CB1 Receptor Heteromers in the Hippocampus: Cannabidiol Blunts $\Delta$ 9-Tetrahydrocannabinol-Induced Cognitive Impairment. Mol. Neurobiol. 2019, 56, 5382-5391. [CrossRef]

89. Samanta, D. Cannabidiol: A Review of Clinical Efficacy and Safety in Epilepsy. Pediatr. Neurol. 2019, 96, 24-29. [CrossRef]

90. Premoli, M.; Aria, F.; Bonini, S.A.; Maccarinelli, G.; Gianoncelli, A.; Della Pina, S.; Tambaro, S.; Memo, M.; Mastinu, A. Cannabidiol: Recent advances and new insights for neuropsychiatric disorders treatment. Life Sci. 2019, 224, 120-127. [CrossRef]

91. Hill, A.J.; Mercier, M.S.; Hill, T.D.M.; Glyn, S.E.; Jones, N.A.; Yamasaki, Y.; Futamura, T.; Duncan, M.; Stott, C.G.; Stephens, G.J.; et al. Cannabidivarin is anticonvulsant in mouse and rat. Br. J. Pharmacol. 2012, 167, 1629-1642. [CrossRef]

92. Vigli, D.; Cosentino, L.; Raggi, C.; Laviola, G.; Woolley-Roberts, M.; De Filippis, B. Chronic treatment with the phytocannabinoid Cannabidivarin (CBDV) rescues behavioural alterations and brain atrophy in a mouse model of Rett syndrome. Neuropharmacology 2018, 140, 121-129. [CrossRef] [PubMed]

93. Zamberletti, E.; Gabaglio, M.; Woolley-Roberts, M.; Bingham, S.; Rubino, T.; Parolaro, D. Cannabidivarin Treatment Ameliorates Autism-Like Behaviors and Restores Hippocampal Endocannabinoid System and Glia Alterations Induced by Prenatal Valproic Acid Exposure in Rats. Front. Cell. Neurosci. 2019, 13, 1-15. [CrossRef] [PubMed]

94. Pretzsch, C.M.; Freyberg, J.; Voinescu, B.; Lythgoe, D.; Horder, J.; Mendez, M.A.; Wichers, R.; Ajram, L.; Ivin, G.; Heasman, M.; et al. Effects of cannabidiol on brain excitation and inhibition systems; a randomised placebo-controlled single dose trial during magnetic resonance spectroscopy in adults with and without autism spectrum disorder. Neuropsychopharmacology 2019, 44, 1398-1405. [CrossRef] [PubMed]

95. Izzo, A.A.; Sharkey, K.A. Cannabinoids and the gut: New developments and emerging concepts. Pharmacol. Ther. 2010, 126, 21-38. [CrossRef] [PubMed]

96. Sharkey, K.A.; Wiley, J.W. The Role of the Endocannabinoid System in the Brain-Gut Axis. Gastroenterology 2016, 151, 252-266. [CrossRef]

97. Taschler, U.; Hasenoehrl, C.; Storr, M.; Schicho, R. Cannabinoid Receptors in Regulating the GI Tract: Experimental Evidence and Therapeutic Relevance. In Handbook of Experimental Pharmacology; Springer: Berlin/Heidelberg, Germany, 2016; Volume 239, pp. 343-362. ISBN 9783319563596.

98. Joshi, N.; Onaivi, E.S. Endocannabinoid System Components: Overview and Tissue Distribution. In Advances in Experimental Medicine and Biology; Springer: Berlin/Heidelberg, Germany, 2019; Volume 1162, pp. 1-12. ISBN 9783030217365.

99. Vera, G.; López-Pérez, A.E.; Uranga, J.A.; Girón, R.; Martín-Fontelles, M.I.; Abalo, R. Involvement of cannabinoid signaling in vincristine-induced gastrointestinal dysmotility in the rat. Front. Pharmacol. 2017, 8, 1-16. [CrossRef]

100. Salaga, M.; Zatorski, H.; Zielińska, M.; Mosinska, P.; Timmermans, J.P.; Kordek, R.; Storr, M.; Fichna, J. Highly selective CB2 receptor agonist A836339 has gastroprotective effect on experimentally induced gastric ulcers in mice. Naunyn. Schmiedebergs. Arch. Pharmacol. 2017, 390, 1015-1027. [CrossRef] 
101. Abalo, R.; Vera, G.; López-Pérez, A.E.; Martnez-Villaluenga, M.; Martín-Fontelles, M.I. The gastrointestinal pharmacology of cannabinoids: Focus on motility. Pharmacology 2012, 90, 1-10. [CrossRef]

102. Malik, Z.; Baik, D.; Schey, R. The Role of Cannabinoids in Regulation of Nausea and Vomiting, and Visceral Pain. Curr. Gastroenterol. Rep. 2015, 17, 9. [CrossRef]

103. Gyires, K.; S Zádori, Z. Role of Cannabinoids in Gastrointestinal Mucosal Defense and Inflammation. Curr. Neuropharmacol. 2016, 14, 935-951. [CrossRef]

104. Hasenoehrl, C.; Taschler, U.; Storr, M.; Schicho, R. The gastrointestinal tract-A central organ of cannabinoid signaling in health and disease. Neurogastroenterol. Motil. 2016, 28, 1765-1780. [CrossRef] [PubMed]

105. Acharya, N.; Penukonda, S.; Shcheglova, T.; Hagymasi, A.T.; Basu, S.; Srivastava, P.K. Endocannabinoid system acts as a regulator of immune homeostasis in the gut. Proc. Natl. Acad. Sci. USA 2017, 114, 5005-5010. [CrossRef] [PubMed]

106. Abalo, R.; Martín-Fontelles, M.I. Cannabis, cannabinoids, and visceral pain. In Handbook of Cannabis and Related Pathologies, Biology, Pharmacology, Diagnosis, and Treatment; Preedy, V., Ed.; Academic Press: Cambridge, MA, USA, 2017; pp. 439-449. ISBN 9780128007563.

107. Camilleri, M. Cannabinoids and gastrointestinal motility: Pharmacology, clinical effects, and potential therapeutics in humans. Neurogastroenterol. Motil. 2018, 30, e13370. [CrossRef] [PubMed]

108. Uranga, J.A.; Vera, G.; Abalo, R. Cannabinoid pharmacology and therapy in gut disorders. Biochem. Pharmacol. 2018, 157, 134-147. [CrossRef] [PubMed]

109. Pinto, L.; Izzo, A.A.; Cascio, M.G.; Bisogno, T.; Hospodar-Scott, K.; Brown, D.R.; Mascolo, N.; Di Marzo, V.; Capasso, F. Endocannabinoids as physiological regulators of colonic propulsion in mice. Gastroenterology 2002, 123, 227-234. [CrossRef] [PubMed]

110. Aviello, G.; Romano, B.; Izzo, A.A. Cannabinoids and gastrointestinal motility: Animal and human studies. Eur. Rev. Med. Pharmacol. Sci. 2008, 12, 81-93.

111. Fioramonti, J.; Bueno, L. Role of cannabinoid receptors in the control of gastrointestinal motility and perception. Expert Rev. Gastroenterol. Hepatol. 2008, 2, 385-397. [CrossRef]

112. Salama, R.A.A.; Abdelsalam, R.M.; Abdel-Salam, O.M.E.; Khattab, M.M.; Salem, N.A.; El-Khyat, Z.A.; Morsy, F.A.; Eldenshary, E.E.D.S. Modulation of gastric acid secretion by cannabinoids in rats. J. Biochem. Mol. Toxicol. 2019, 33. [CrossRef]

113. Brusberg, M.; Arvidsson, S.; Kang, D.; Larsson, H.; Lindström, E.; Martinez, V. CB1 receptors mediate the analgesic effects of cannabinoids on colorectal distension-induced visceral pain in rodents. J. Neurosci. 2009, 29, 1554-1564. [CrossRef]

114. Alhouayek, M.; Muccioli, G.G. The endocannabinoid system in inflammatory bowel diseases: From pathophysiology to therapeutic opportunity. Trends Mol. Med. 2012, 18, 615-625. [CrossRef]

115. Amin, M.R.; Ali, D.W. Pharmacology of Medical Cannabis. In Recent Advances in Cannabinoid Physiology and Pathology. Advances in Experimental Medicine and Biology; Bukiya, A., Ed.; Springer: Cham, Switzerland, 2019; pp. 151-165.

116. Cogan, P.S. On healthcare by popular appeal: Critical assessment of benefit and risk in cannabidiol based dietary supplements. Expert Rev. Clin. Pharmacol. 2019, 12, 501-511. [CrossRef] [PubMed]

117. Williamson, E.M.; Liu, X.; Izzo, A.A. Trends in use, pharmacology, and clinical applications of emerging herbal nutraceuticals. Br. J. Pharmacol. 2019. [CrossRef] [PubMed]

118. Drossman, D.A. Functional gastrointestinal disorders: History, pathophysiology, clinical features, and Rome IV. Gastroenterology 2016, 150, 1262-1279.e2. [CrossRef] [PubMed]

119. Hadjivasilis, A.; Tsioutis, C.; Michalinos, A.; Ntourakis, D.; Christodoulou, D.K.; Agouridis, A.P. New insights into irritable bowel syndrome: From pathophysiology to treatment. Ann. Gastroenterol. 2019, 32, 554-564. [CrossRef] [PubMed]

120. Hellström, P.M. Pathophysiology of the irritable bowel syndrome-Reflections of today. Best Pract. Res. Clin. Gastroenterol. 2019, 40-41. [CrossRef]

121. Labanski, A.; Langhorst, J.; Engler, H.; Elsenbruch, S. Stress and the brain-gut axis in functional and chronic-inflammatory gastrointestinal diseases: A transdisciplinary challenge. Psychoneuroendocrinology 2020, 111. [CrossRef]

122. Grad, S.; Dumitrascu, D.L. Irritable Bowel Syndrome Subtypes: New Names for Old Medical Conditions. Dig. Dis. 2020, 38, 122-127. [CrossRef] 
123. Chester, G.B.; Dahl, C.J.; Everingham, M.; Jackson, D.M.; Marchant-Williams, H.; Starmer, G.A. The effect of cannabinoids on intestinal motility and their antinociceptive effect in mice. Br. J. Pharmacol. 1973, 49, 588-594. [CrossRef]

124. Shook, J.E.; Burks, T.F. Psychoactive cannabinoids reduce gastrointestinal propulsion and motility in rodents. J. Pharmacol. Exp. Ther. 1989, 249, 444-449.

125. Fride, E.; Ponde, D.; Breuer, A.; Hanuš, L. Peripheral, but not central effects of cannabidiol derivatives: Mediation by CB1 and unidentified receptors. Neuropharmacology 2005, 48, 1117-1129. [CrossRef]

126. Izzo, A.A.; Capasso, R.; Aviello, G.; Borrelli, F.; Romano, B.; Piscitelli, F.; Gallo, L.; Capasso, F.; Orlando, P.; Di Marzo, V. Inhibitory effect of cannabichromene, a major non-psychotropic cannabinoid extracted from Cannabis sativa, on inflammation-induced hypermotility in mice. Br. J. Pharmacol. 2012, 166, 1444-1460. [CrossRef] [PubMed]

127. Capasso, R.; Borrelli, F.; Aviello, G.; Romano, B.; Scalisi, C.; Capasso, F.; Izzo, A.A. Cannabidiol, extracted from Cannabis sativa, selectively inhibits inflammatory hypermotility in mice. Br. J. Pharmacol. 2008, 154, 1001-1008. [CrossRef] [PubMed]

128. Pagano, E.; Romano, B.; Iannotti, F.A.; Parisi, O.A.; D'Armiento, M.; Pignatiello, S.; Coretti, L.; Lucafò, M.; Venneri, T.; Stocco, G.; et al. The non-euphoric phytocannabinoid cannabidivarin counteracts intestinal inflammation in mice and cytokine expression in biopsies from UC pediatric patients. Pharmacol. Res. 2019, 149, 104464. [CrossRef] [PubMed]

129. Izzo, A.A.; Pinto, L.; Borrelli, F.; Capasso, R.; Mascolo, N.; Capasso, F. Central and peripheral cannabinoid modulation of gastrointestinal transit in physiological states or during the diarrhoea induced by croton oil. Br. J. Pharmacol. 2000, 129, 1627-1632. [CrossRef] [PubMed]

130. Izzo, A.A.; Fezza, F.; Capasso, R.; Bisogno, T.; Pinto, L.; Iuvone, T.; Esposito, G.; Mascolo, N.; Di Marzo, V.; Capasso, F. Cannabinoid CB1-receptor mediated regulation of gastrointestinal motility in mice in a model of intestinal inflammation. Br. J. Pharmacol. 2001, 134, 563-570. [CrossRef] [PubMed]

131. Pagano, E.; Capasso, R.; Piscitelli, F.; Romano, B.; Parisi, O.A.; Finizio, S.; Lauritano, A.; Di Marzo, V.; Izzo, A.A.; Borrelli, F. An orally active Cannabis extract with high content in cannabidiol attenuates chemically-induced intestinal inflammation and hypermotility in the mouse. Front. Pharmacol. 2016, 7, 1-12. [CrossRef] [PubMed]

132. Lin, X.H.; Yuece, B.; Li, Y.Y.; Feng, Y.J.; Feng, J.Y.; Yu, L.Y.; Li, K.; Li, Y.N.; Storr, M. A novel CB receptor GPR55 and its ligands are involved in regulation of gut movement in rodents. Neurogastroenterol. Motil. 2011, 23. [CrossRef]

133. Wong, B.S.; Camilleri, M.; Busciglio, I.; Carlson, P.; Szarka, L.A.; Burton, D.; Zinsmeister, A.R. Pharmacogenetic Trial of a Cannabinoid Agonist Shows Reduced Fasting Colonic Motility in Patients With Nonconstipated Irritable Bowel Syndrome. Gastroenterology 2011, 141, 1638-1647.e7. [CrossRef]

134. Wong, B.S.; Camilleri, M.; Eckert, D.; Carlson, P.; Ryks, M.; Burton, D.; Zinsmeister, A.R. Randomized pharmacodynamic and pharmacogenetic trial of dronabinol effects on colon transit in irritable bowel syndrome-diarrhea. Neurogastroenterol. Motil. 2012, 24. [CrossRef]

135. Formukong, E.A.; Evans, A.T.; Evans, F.J. Analgesic and antiinflammatory activity of constituents of Cannabis sativa L. Inflammation 1988, 12, 361-371. [CrossRef]

136. Sanson, M.; Bueno, L.; Fioramonti, J. Involvement of cannabinoid receptors in inflammatory hypersensitivity to colonic distension in rats. Neurogastroenterol. Motil. 2006, 18, 949-956. [CrossRef] [PubMed]

137. Kikuchi, A.; Ohashi, K.; Sugie, Y.; Sugimoto, H.; Omura, H. Pharmacological evaluation of a novel cannabinoid 2 (CB2) ligand, PF-03550096, in vitro and in vivo by using a rat model of visceral hypersensitivity. J. Pharmacol. Sci. 2008, 106, 219-224. [CrossRef] [PubMed]

138. Booker, L.; Naidu, P.S.; Razdan, R.K.; Mahadevan, A.; Lichtman, A.H. Evaluation of prevalent phytocannabinoids in the acetic acid model of visceral nociception. Drug Alcohol Depend. 2009, 105, 42-47. [CrossRef] [PubMed]

139. Hong, S.; Fan, J.; Kemmerer, E.S.; Evans, S.; Li, Y.; Wiley, J.W. Reciprocal changes in vanilloid (TRPV1) and endocannabinoid (CB1) receptors contribute to visceral hyperalgesia in the water avoidance stressed rat. Gut 2009, 58, 202-210. [CrossRef] [PubMed]

140. Ravnefjord, A.; Brusberg, M.; Kang, D.; Bauer, U.; Larsson, H.; Lindström, E.; Martinez, V. Involvement of the transient receptor potential vanilloid 1 (TRPV1) in the development of acute visceral hyperalgesia during colorectal distension in rats. Eur. J. Pharmacol. 2009, 611, 85-91. [CrossRef] [PubMed] 
141. Naidu, P.S.; Booker, L.; Cravatt, B.F.; Lichtman, A.H. Synergy between enzyme inhibitors of fatty acid amide hydrolase and cyclooxygenase in visceral nociception. J. Pharmacol. Exp. Ther. 2009, 329, 48-56. [CrossRef]

142. Iwata, Y.; Ando, K.; Taniguchi, K.; Koba, N.; Sugiura, A.; Sudo, M. Identification of a highly potent and selective CB2 agonist, RQ-00202730, for the treatment of irritable bowel syndrome. Bioorganic Med. Chem. Lett. 2015, 25, 236-240. [CrossRef]

143. Klooker, T.K.; Leliefeld, K.E.M.; Van Den Wijngaard, R.M.; Boeckxstaens, G.E.E. The cannabinoid receptor agonist delta- 9- tetrahydrocannabinol does not affect visceral sensitivity to rectal distension in healthy volunteers and IBS patients. Neurogastroenterol. Motil. 2011, 23, 30. [CrossRef]

144. De Vries, M.; van Rijckevorsel, D.C.M.; Vissers, K.C.P.; Wilder-Smith, O.H.G.; van Goor, H. Tetrahydrocannabinol Does Not Reduce Pain in Patients With Chronic Abdominal Pain in a Phase 2 Placebo-controlled Study. Clin. Gastroenterol. Hepatol. 2017, 15, 1079-1086.e4. [CrossRef]

145. Buggy, D.J.; Toogood, L.; Maric, S.; Sharpe, P.; Lambert, D.G.; Rowbotham, D.J. Lack of analgesic efficacy of oral $\delta$-9-tetrahydrocannabinol in postoperative pain. Pain 2003, 106, 169-172. [CrossRef]

146. Guan, Q. A Comprehensive Review and Update on the Pathogenesis of Inflammatory Bowel Disease. J. Immunol. Res. 2019, 2019. [CrossRef] [PubMed]

147. Lamb, C.A.; Kennedy, N.A.; Raine, T.; Hendy, P.A.; Smith, P.J.; Limdi, J.K.; Hayee, B.; Lomer, M.C.E.; Parkes, G.C.; Selinger, C.; et al. British Society of Gastroenterology consensus guidelines on the management of inflammatory bowel disease in adults. Gut 2019, 68, s1-s106. [CrossRef] [PubMed]

148. Eichele, D.D.; Young, R. Medical Management of Inflammatory Bowel Disease. Surg. Clin. North Am. 2019, 99, 1223-1235. [CrossRef] [PubMed]

149. Tamilarasan, A.G.; Cunningham, G.; Irving, P.M.; Samaan, M.A. Recent advances in monoclonal antibody therapy in IBD: Practical issues. Frontline Gastroenterol. 2019, 10, 409-416. [CrossRef] [PubMed]

150. Quezada, S.M.; McLean, L.P.; Cross, R.K. Adverse events in IBD therapy: The 2018 update. Expert Rev. Gastroenterol. Hepatol. 2018, 12, 1183-1191. [CrossRef]

151. Picardo, S.; Kaplan, G.G.; Sharkey, K.A.; Seow, C.H. Insights into the role of cannabis in the management of inflammatory bowel disease. Therap. Adv. Gastroenterol. 2019, 12, 175628481987097. [CrossRef]

152. Kienzl, M.; Storr, M.; Schicho, R. Cannabinoids and Opioids in the Treatment of Inflammatory Bowel Diseases. Clin. Transl. Gastroenterol. 2020, 11, e00120. [CrossRef]

153. Lal, S.; Prasad, N.; Ryan, M.; Tangri, S.; Silverberg, M.S.; Gordon, A.; Steinhart, H. Cannabis use amongst patients with inflammatory bowel disease. Eur. J. Gastroenterol. Hepatol. 2011, 23, 891-896. [CrossRef]

154. Ravikoff Allegretti, J.; Courtwright, A.; Lucci, M.; Korzenik, J.R.; Levine, J. Marijuana Use Patterns Among Patients with Inflammatory Bowel Disease. Inflamm. Bowel Dis. 2013, 19, 2809-2814. [CrossRef]

155. Storr, M.; Devlin, S.; Kaplan, G.G.; Panaccione, R.; Andrews, C.N. Cannabis use provides symptom relief in patients with inflammatory bowel disease but is associated with worse disease prognosis in patients with Crohn's disease. Inflamm. Bowel Dis. 2014, 20, 472-480. [CrossRef]

156. Esposito, G.; Filippis, D.D.; Cirillo, C.; Iuvone, T.; Capoccia, E.; Scuderi, C.; Steardo, A.; Cuomo, R.; Steardo, L. Cannabidiol in Inflammatory Bowel Diseases: A Brief Overview. Phyther. Res. 2013, 27, 633-636. [CrossRef]

157. Leinwand, K.L.; Gerich, M.E.; Hoffenberg, E.J.; Collins, C.B. Manipulation of the Endocannabinoid System in Colitis. Inflamm. Bowel Dis. 2017, 23, 192-199. [CrossRef] [PubMed]

158. Couch, D.G.; Maudslay, H.; Doleman, B.; Lund, J.N.; O'Sullivan, S.E. The Use of Cannabinoids in Colitis: A Systematic Review and Meta-Analysis. Inflamm. Bowel Dis. 2018, 24, 680-697. [CrossRef]

159. Turcotte, C.; Chouinard, F.; Lefebvre, J.S.; Flamand, N. Regulation of inflammation by cannabinoids, the endocannabinoids 2-arachidonoyl-glycerol and arachidonoyl-ethanolamide, and their metabolites. J. Leukoc. Biol. 2015, 97, 1049-1070. [CrossRef] [PubMed]

160. Zoppi, S.; Madrigal, J.L.M.; Pérez-Nievas, B.G.; Marín-Jiménez, I.; Caso, J.R.; Alou, L.; García-Bueno, B.; Colón, A.; Manzanares, J.; Luisa Gómez-Lus, M.; et al. Endogenous cannabinoid system regulates intestinal barrier function in vivo through cannabinoid type 1 receptor activation. Am. J. Physiol.-Gastrointest. Liver Physiol. 2012, 302, 565-571. [CrossRef] [PubMed]

161. Izzo, A.A.; Capasso, F.; Costagliola, A.; Bisogno, T.; Marsicano, G.; Ligresti, A.; Matias, I.; Capasso, R.; Pinto, L.; Borrelli, F.; et al. An endogenous cannabinoid tone attenuates cholera toxin-induced fluid accumulation in mice. Gastroenterology 2003, 125, 765-774. [CrossRef] 
162. Mathison, R.; Ho, W.; Pittman, Q.J.; Davison, J.S.; Sharkey, K.A. Effects of cannabinoid receptor-2 activation on accelerated gastrointestinal transit in lipopolysaccharide-treated rats. Br. J. Pharmacol. 2004, 142, 1247-1254. [CrossRef]

163. De Filippis, D.; Esposito, G.; Cirillo, C.; Cipriano, M.; de Winter, B.Y.; Scuderi, C.; Sarnelli, G.; Cuomo, R.; Steardo, L.; de Man, J.G.; et al. Cannabidiol reduces intestinal inflammation through the control of neuroimmune axis. PLoS ONE 2011, 6, e28159. [CrossRef]

164. Schicho, R.; Storr, M. Topical and systemic cannabidiol improves trinitrobenzene sulfonic acid colitis in mice. Pharmacology 2012, 89, 149-155. [CrossRef]

165. Jamontt, J.M.; Molleman, A.; Pertwee, R.G.; Parsons, M.E. The effects of $\Delta$ 9-tetrahydrocannabinol and cannabidiol alone and in combination on damage, inflammation and in vitro motility disturbances in rat colitis. Br. J. Pharmacol. 2010, 160, 712-723. [CrossRef]

166. Borrelli, F.; Aviello, G.; Romano, B.; Orlando, P.; Capasso, R.; Maiello, F.; Guadagno, F.; Petrosino, S.; Capasso, F.; Di Marzo, V.; et al. Cannabidiol, a safe and non-psychotropic ingredient of the marijuana plant Cannabis sativa, is protective in a murine model of colitis. J. Mol. Med. 2009, 87, 1111-1121. [CrossRef] [PubMed]

167. Borrelli, F.; Fasolino, I.; Romano, B.; Capasso, R.; Maiello, F.; Coppola, D.; Orlando, P.; Battista, G.; Pagano, E.; Di Marzo, V.; et al. Beneficial effect of the non-psychotropic plant cannabinoid cannabigerol on experimental inflammatory bowel disease. Biochem. Pharmacol. 2013, 85, 1306-1316. [CrossRef] [PubMed]

168. Romano, B.; Borrelli, F.; Fasolino, I.; Capasso, R.; Piscitelli, F.; Cascio, M.G.; Pertwee, R.G.; Coppola, D.; Vassallo, L.; Orlando, P.; et al. The cannabinoid TRPA1 agonist cannabichromene inhibits nitric oxide production in macrophages and ameliorates murine colitis. Br. J. Pharmacol. 2013, 169, 213-229. [CrossRef] [PubMed]

169. Greco, M.; Varriale, G.; Coppola, G.; Operto, F.; Verrotti, A.; Iezzi, M.L. Investigational small molecules in phase II clinical trials for the treatment of epilepsy. Expert Opin. Investig. Drugs 2018, 27, 971-979. [CrossRef] [PubMed]

170. De Petrocellis, L.; Di Marzo, V. Non-CB1, Non-CB2 receptors for endocannabinoids, plant cannabinoids, and synthetic cannabimimetics: Focus on G-protein-coupled receptors and transient receptor potential channels. J. Neuroimmune Pharmacol. 2010, 5, 103-121. [CrossRef] [PubMed]

171. Kun, J.; Szitter, I.; Kemény, Á.; Perkecz, A.; Kereskai, L.; Pohóczky, K.; Vincze, Á.; Gódi, S.; Szabó, I.; Szolcsányi, J.; et al. Upregulation of the transient receptor potential ankyrin 1 ion channel in the inflamed human and mouse colon and its protective roles. PLoS ONE 2014, 9, e108164. [CrossRef]

172. Khalil, M.; Alliger, K.; Weidinger, C.; Yerinde, C.; Wirtz, S.; Becker, C.; Engel, M.A. Functional role of transient receptor potential channels in immune cells and epithelia. Front. Immunol. 2018, 9, 1-7. [CrossRef]

173. Rizopoulos, T.; Papadaki-Petrou, H.; Assimakopoulou, M. Expression Profiling of the Transient Receptor Potential Vanilloid (TRPV) Channels 1, 2, 3 and 4 in Mucosal Epithelium of Human Ulcerative Colitis. Cells 2018, 7, 61. [CrossRef]

174. Ligresti, A.; Cascio, M.G.; Pryce, G.; Kulasegram, S.; Beletskaya, I.; De Petrocellis, L.; Saha, B.; Mahadevan, A.; Visintin, C.; Wiley, J.L.; et al. New potent and selective inhibitors of anandamide reuptake with antispastic activity in a mouse model of multiple sclerosis. Br. J. Pharmacol. 2006, 147, 83-91. [CrossRef]

175. Naftali, T.; Mechulam, R.; Marii, A.; Gabay, G.; Stein, A.; Bronshtain, M.; Laish, I.; Benjaminov, F.; Konikoff, F.M. Low-Dose Cannabidiol Is Safe but Not Effective in the Treatment for Crohn's Disease, a Randomized Controlled Trial. Dig. Dis. Sci. 2017, 62, 1615-1620. [CrossRef]

176. Irving, P.M.; Iqbal, T.; Nwokolo, C.; Subramanian, S.; Bloom, S.; Prasad, N.; Hart, A.; Murray, C.; Lindsay, J.O.; Taylor, A.; et al. A Randomized, Double-blind, Placebo-controlled, Parallel-group, Pilot Study of Cannabidiol-rich Botanical Extract in the Symptomatic Treatment of Ulcerative Colitis. Inflamm. Bowel Dis. 2018, 24, 714-724. [CrossRef] [PubMed]

177. Kafil, T.S.; Nguyen, T.M.; MacDonald, J.K.; Chande, N. Cannabis for the treatment of Crohn's disease. Cochrane Database Syst. Rev. 2018. [CrossRef] [PubMed]

178. Kafil, T.S.; Nguyen, T.M.; MacDonald, J.K.; Chande, N. Cannabis for the treatment of ulcerative colitis. Cochrane Database Syst. Rev. 2018. [CrossRef] [PubMed]

179. Dekker, E.; Tanis, P.J.; Vleugels, J.L.A.; Kasi, P.M.; Wallace, M.B. Colorectal cancer. Lancet 2019, 394, 1467-1480. [CrossRef] 
180. Rawla, P.; Sunkara, T.; Barsouk, A. Epidemiology of colorectal cancer: Incidence, mortality, survival, and risk factors. Prz. Gastroenterol. 2019, 14, 89-103. [CrossRef] [PubMed]

181. Bar-Lev Schleider, L.; Mechoulam, R.; Lederman, V.; Hilou, M.; Lencovsky, O.; Betzalel, O.; Shbiro, L.; Novack, V. Prospective analysis of safety and efficacy of medical cannabis in large unselected population of patients with cancer. Eur. J. Intern. Med. 2018, 49, 37-43. [CrossRef]

182. Kleckner, A.S.; Kleckner, I.R.; Kamen, C.S.; Tejani, M.A.; Janelsins, M.C.; Morrow, G.R.; Peppone, L.J. Opportunities for cannabis in supportive care in cancer. Ther. Adv. Med. Oncol. 2019, 11, 175883591986636. [CrossRef]

183. Venerito, M.; Link, A.; Rokkas, T.; Malfertheiner, P. Review: Gastric cancer-Clinical aspects. Helicobacter 2019, 24, 1-5. [CrossRef]

184. Wang, D.; Wang, H.; Ning, W.; Backlund, M.G.; Dey, S.K.; DuBois, R.N. Loss of Cannabinoid Receptor 1 Accelerates Intestinal Tumor Growth. Cancer Res. 2008, 68, 6468-6476. [CrossRef]

185. Cianchi, F.; Papucci, L.; Schiavone, N.; Lulli, M.; Magnelli, L.; Vinci, M.C.; Messerini, L.; Manera, C.; Ronconi, E.; Romagnani, P.; et al. Cannabinoid receptor activation induces apoptosis through tumor necrosis factor $\alpha$-mediated ceramide de novo synthesis in colon cancer cells. Clin. Cancer Res. 2008, 14, 7691-7700. [CrossRef]

186. Velasco, G.; Sánchez, C.; Guzmán, M. Towards the use of cannabinoids as antitumour agents. Nat. Rev. Cancer 2012, 12, 436-444. [CrossRef] [PubMed]

187. Dariš, B.; Verboten, M.T.; Knez, Ž.; Ferk, P. Cannabinoids in cancer treatment: Therapeutic potential and legislation. Bosn. J. Basic Med. Sci. 2019, 19, 14-23. [CrossRef] [PubMed]

188. McAllister, S.D.; Soroceanu, L.; Desprez, P.-Y. The Antitumor Activity of Plant-Derived Non-Psychoactive Cannabinoids. J. Neuroimmune Pharmacol. 2015, 10, 255-267. [CrossRef] [PubMed]

189. Kis, B.; Ifrim, F.C.; Buda, V.; Avram, S.; Pavel, I.Z.; Antal, D.; Paunescu, V.; Dehelean, C.A.; Ardelean, F.; Diaconeasa, Z.; et al. Cannabidiol-From plant to human body: A promising bioactive molecule with multi-target effects in cancer. Int. J. Mol. Sci. 2019, 20, 5905. [CrossRef] [PubMed]

190. Sharafi, G.; He, H.; Nikfarjam, M. Potential Use of Cannabinoids for the Treatment of Pancreatic Cancer. J. Pancreat. Cancer 2019, 5, 1-7. [CrossRef] [PubMed]

191. Kosgodage, U.S.; Uysal-Onganer, P.; MacLatchy, A.; Mould, R.; Nunn, A.V.; Guy, G.W.; Kraev, I.; Chatterton, N.P.; Thomas, E.L.; Inal, J.M.; et al. Cannabidiol Affects Extracellular Vesicle Release, miR21 and miR126, and Reduces Prohibitin Protein in Glioblastoma Multiforme Cells. Transl. Oncol. 2019, 12, 513-522. [CrossRef]

192. Scott, K.A.; Shah, S.; Dalgleish, A.G.; Liu, W.M. Enhancing the activity of cannabidiol and other cannabinoids in vitro through modifications to drug combinations and treatment schedules. Anticancer Res. 2013, 33, 4373-4380.

193. Sultan, A.S.; Marie, M.A.; Sheweita, S.A. Novel mechanism of cannabidiol-induced apoptosis in breast cancer cell lines. Breast 2018, 41, 34-41. [CrossRef]

194. Kargl, J.; Andersen, L.; Hasenöhrl, C.; Feuersinger, D.; Stančic, A.; Fauland, A.; Magnes, C.; El-Heliebi, A.; Lax, S.; Uranitsch, S.; et al. GPR55 promotes migration and adhesion of colon cancer cells indicating a role in metastasis. Br. J. Pharmacol. 2016, 173, 142-154. [CrossRef]

195. Kargl, J.; Haybaeck, J.; Stančić, A.; Andersen, L.; Marsche, G.; Heinemann, A.; Schicho, R. O-1602, an atypical cannabinoid, inhibits tumor growth in colitis-associated colon cancer through multiple mechanisms. J. Mol. Med. 2013, 91, 449-458. [CrossRef]

196. Sreevalsan, S.; Joseph, S.; Jutooru, I.; Chadalapaka, G.; Safe, S.H. Induction of apoptosis by cannabinoids in prostate and colon cancer cells is phosphatase dependent. Anticancer Res. 2011, 31, 3799-3807. [PubMed]

197. Aviello, G.; Romano, B.; Borrelli, F.; Capasso, R.; Gallo, L.; Piscitelli, F.; Di Marzo, V.; Izzo, A.A. Chemopreventive effect of the non-psychotropic phytocannabinoid cannabidiol on experimental colon cancer. J. Mol. Med. 2012, 90, 925-934. [CrossRef] [PubMed]

198. Jeong, S.; Kim, B.G.; Kim, D.Y.; Kim, B.R.; Kim, J.L.; Park, S.H.; Na, Y.J.; Jo, M.J.; Yun, H.K.; Jeong, Y.A.; et al. Cannabidiol overcomes oxaliplatin resistance by enhancing NOS3- and SOD2-Induced autophagy in human colorectal cancer cells. Cancers (Basel) 2019, 11, 781. [CrossRef] [PubMed]

199. Jeong, S.; Yun, H.K.; Jeong, Y.A.; Jo, M.J.; Kang, S.H.; Kim, J.L.; Kim, D.Y.; Park, S.H.; Kim, B.R.; Na, Y.J.; et al. Cannabidiol-induced apoptosis is mediated by activation of Noxa in human colorectal cancer cells. Cancer Lett. 2019, 447, 12-23. [CrossRef] [PubMed] 
200. Romano, B.; Borrelli, F.; Pagano, E.; Cascio, M.G.; Pertwee, R.G.; Izzo, A.A. Inhibition of colon carcinogenesis by a standardized Cannabis sativa extract with high content of cannabidiol. Phytomedicine 2014, 21, 631-639. [CrossRef]

201. Honarmand, M.; Namazi, F.; Mohammadi, A.; Nazifi, S. Can cannabidiol inhibit angiogenesis in colon cancer? Comp. Clin. Path. 2019, 28, 165-172. [CrossRef]

202. Zhang, X.; Qin, Y.; Pan, Z.; Li, M.; Liu, X.; Chen, X.; Qu, G.; Zhou, L.; Xu, M.; Zheng, Q.; et al. Cannabidiol induces cell cycle arrest and cell apoptosis in human gastric cancer SGC-7901 cells. Biomolecules 2019, 9, 1-17. [CrossRef]

203. Jeong, S.; Jo, M.J.; Yun, H.K.; Kim, D.Y.; Kim, B.R.; Kim, J.L.; Park, S.H.; Na, Y.J.; Jeong, Y.A.; Kim, B.G.; et al. Cannabidiol promotes apoptosis via regulation of XIAP/Smac in gastric cancer. Cell Death Dis. 2019, 10. [CrossRef]

204. Nallathambi, R.; Mazuz, M.; Namdar, D.; Shik, M.; Namintzer, D.; Vinayaka, A.C.; Ion, A.; Faigenboim, A.; Nasser, A.; Laish, I.; et al. Identification of synergistic interaction between cannabis-derived compounds for cytotoxic activity in colorectal cancer cell lines and colon polyps that induces apoptosis-related cell death and distinct gene expression. Cannabis Cannabinoid Res. 2018, 3, 120-135. [CrossRef]

205. Hijiya, N.; Shibata, T.; Daa, T.; Hamanaka, R.; Uchida, T.; Matsuura, K.; Tsukamoto, Y.; Nakada, C.; Iha, H.; Inomata, M.; et al. Overexpression of cannabinoid receptor 1 in esophageal squamous cell carcinoma is correlated with metastasis to lymph nodes and distant organs, and poor prognosis. Pathol. Int. 2017, 67, 83-90. [CrossRef]

206. Duran, M.; Pérez, E.; Abanades, S.; Vidal, X.; Saura, C.; Majem, M.; Arriola, E.; Rabanal, M.; Pastor, A.; Farré, M.; et al. Preliminary efficacy and safety of an oromucosal standardized cannabis extract in chemotherapy-induced nausea and vomiting. Br. J. Clin. Pharmacol. 2010, 70, 656-663. [CrossRef] [PubMed]

207. Mersiades, A.J.; Tognela, A.; Haber, P.S.; Stockler, M.; Lintzeris, N.; Simes, J.; McGregor, I.; Olver, I.; Allsop, D.J.; Gedye, C.; et al. Oral cannabinoid-rich THC/CBD cannabis extract for secondary prevention of chemotherapy-induced nausea and vomiting: A study protocol for a pilot and definitive randomised double-blind placebo-controlled trial (CannabisCINV). BMJ Open 2018, 8, e020745. [CrossRef] [PubMed]

208. Parker, L.A.; Rock, E.M.; Limebeer, C.L. Regulation of nausea and vomiting by cannabinoids. Br. J. Pharmacol. 2011, 163, 1411-1422. [CrossRef] [PubMed]

209. Sharkey, K.A.; Darmani, N.A.; Parker, L.A. Regulation of nausea and vomiting by cannabinoids and the endocannabinoid system. Eur. J. Pharmacol. 2014, 722, 134-146. [CrossRef] [PubMed]

210. Rock, E.M.; Goodwin, J.M.; Limebeer, C.L.; Breuer, A.; Pertwee, R.G.; Mechoulam, R.; Parker, L.A. Interaction between non-psychotropic cannabinoids in marihuana: Effect of cannabigerol (CBG) on the anti-nausea or anti-emetic effects of cannabidiol (CBD) in rats and shrews. Psychopharmacology (Berl.) 2011, 215, 505-512. [CrossRef] [PubMed]

211. Galli, J.A.; Sawaya, R.A.; Friedenberg, F.K. Cannabinoid hyperemesis syndrome. Curr. Drug Abuse Rev. 2011, 4, 241-249. [CrossRef]

212. Ruffle, J.K.; Bajgoric, S.; Samra, K.; Chandrapalan, S.; Aziz, Q.; Farmer, A.D. Cannabinoid hyperemesis syndrome: An important differential diagnosis of persistent unexplained vomiting. Eur. J. Gastroenterol. Hepatol. 2015, 27, 1403-1408. [CrossRef]

213. Hasler, W.L.; Levinthal, D.J.; Tarbell, S.E.; Adams, K.A.; Li, B.U.K.; Issenman, R.M.; Sarosiek, I.; Jaradeh, S.S.; Sharaf, R.N.; Sultan, S.; et al. Cyclic vomiting syndrome: Pathophysiology, comorbidities, and future research directions. Neurogastroenterol. Motil. 2019, 31, 1-10. [CrossRef]

214. Abalo, R.; Cabezos, P.A.; Vera, G.; López-miranda, V.; Herradón, E.; Martín-fontelles, M.I. Cannabinoid-induced delayed gastric emptying is selectively increased upon intermittent administration in the rat: Role of CB1 receptors. Neurogastroenterol. Motil. 2011, 23, 457-468. [CrossRef]

215. Abalo, R.; Cabezos, P.A.; López-Miranda, V.; Vera, G.; González, C.; Castillo, M.; Fernández-Pujol, R.; Martín, M.I. Selective lack of tolerance to delayed gastric emptying after daily administration of WIN 55,212-2 in the rat. Neurogastroenterol. Motil. 2009, 21, 22-24. [CrossRef]

216. Cuba, L.F.; Salum, F.G.; Cherubini, K.; Figueiredo, M.A.Z. Cannabidiol: An alternative therapeutic agent for oral mucositis? J. Clin. Pharm. Ther. 2017, 42, 245-250. [CrossRef]

217. Klein, M.; de Quadros De Bortolli, J.; Guimarães, F.S.; Salum, F.G.; Cherubini, K.; de Figueiredo, M.A.Z. Effects of cannabidiol, a Cannabis sativa constituent, on oral wound healing process in rats: Clinical and histological evaluation. Phyther. Res. 2018, 32, 2275-2281. [CrossRef] [PubMed] 
218. Gotfried, J.; Kataria, R.; Schey, R. Review: The Role of Cannabinoids on Esophageal Function-What We Know Thus Far. Cannabis Cannabinoid Res. 2017, 2, 252-258. [CrossRef] [PubMed]

219. Beaumont, H.; Jensen, J.; Carlsson, A.; Ruth, M.; Lehmann, A.; Boeckxstaens, G.E. Effect of $\Delta$ 9-tetrahydrocannabinol, a cannabinoid receptor agonist, on the triggering of transient lower oesophageal sphincter relaxations in dogs and humans. Br. J. Pharmacol. 2009, 156, 153-162. [CrossRef] [PubMed]

(C) 2020 by the authors. Licensee MDPI, Basel, Switzerland. This article is an open access article distributed under the terms and conditions of the Creative Commons Attribution (CC BY) license (http://creativecommons.org/licenses/by/4.0/). 